\title{
Alternative Tourisms in Romania: The Role of Culture and Ecology
}

\section{David Turnock ${ }^{1}$}

\begin{abstract}
Given the challenge of rebuilding a tourist industry depressed by the stagnation of the economy during the 1980s, combined with the growing poverty problem especially in rural areas, the Romanian government decided to encourage alternative tourisms through fiscal incentives and projecrs of ecological reconstruction. Earlier insustained initiatives were revived, with substantial foreign assistance, and a substantial rural network is now in place. The paper explores this successful chapter in the country's economic restructuring with particular reference to specific mountain regions with outstanding cultural and ecological resources. It also shows how further programme in ecological reconstruction could provide further opportunity in mountains and also in the Danube Delta where the emphasis now rests firmly on conservation.
\end{abstract}

Key words: Culture, Ecology, Romania and Tourism

\footnotetext{
Geography Department, The University,
} Leicester LE1 7RH, U.K.

\section{Introduction}

A cultural approach to tourism builds on the work of older tourist societies like Astra (1872), Karpatenverein (1880) and the Tourist Information Office (1937) but momentum was lost by the unrelenting 'top-down' ethos of the communist period. Archaeological and historical monuments - like the Dacian fortresses, the Greek trading centre of Histria, Stephen the Great's monasteries and the great wealth in churches such as those in the Brâncovan style in Wallachia and the wooden churches of Maramureş have been well-preserved but have hardly been fully integrated into the tourist circuit. Likewise the landscape, wild life and flora that provide much scope for an ecologically-oriented tourism. Currently these resources are being promoted along with the idea of Bucharest music festivals and summer theatres for artists of National Opera and Operatta Theatre - as 'flagships' for tour operators. The European Cultural Centre in Bucharest has launched a series of publications called 'Romania: a Cultural Guide' whose first issue on 'Heritage Tourism and Monasteries' was followed in 1999 by 'Heritage Tourism \& Interethnic Transylvania' and 'Heritage Tourism and Bucharest: a City of Contrasts'. Such promotion builds on a small number of museums like the Bucharest Village Museum of the 1930 s (restored in 2003 after a serious fire and now attracting a quarter of a million visitors annually), Sinaia Palace and Cotroceni National Museum. A further dimension resides in sporting programmes such as the golf school project at Breaza's Lac Verde (complemented by new courses at Pianu de Jos (Alba) and 'Golfresort' Recaş (Timiş): the latter laid out in 2006 on 34 ha of former cattle grazing by Romanian expatriate Dan Liviu returning from 20 years in Germany.

Such facilities are now required by wealthy Romanians who can afford the $€_{3,000}$ for kitting-out at special shops now available in Bucharest. But there is also scope for 'extreme sports' linked with thrilling sensations and 'motivational and business tourism' along with conferences and receptions for companies wanting to invest in training, leisure and entertainment programmes for employees. Strong- er support for local initiatives could see the revival of equestrian tourism at Sâmbăta in the Făgăraş Depression, based on the local Lipizanner thoroughreds kept in the meadows around the 18th century castle of Count Bruckenthal since 1874; in an area that also embraces the Sâmbăta Monastery, rebuilt during 1926-36 along with its school for painting icons on glass. But villages have diverse cultural values. In 1999 the press gave attention to a plan for a Medieval tourist complex in Rucăr by a Swiss travel agency working with the famous local wood carver Nicolae Cocârleț. Located at Valea lui Ivan near Pecineagu Dam the complex was to include cottages within a massive perimeter of wooden fencing with completion anticipated in 2000. Villages are now seen as major tourist resources in the context of landscape (through climate, vegetation and topography), economy (orchards, vineyards, pastures, fisheries and hunting grounds) and culture (ethnography, folklore, arts, handicrafts and monuments). Developing alternative tourisms does not require heavy investment but it can generate employment (especially in the context of pluriactivity) and contribute to sustainability in fragile environments while overcoming some of inequalities in the mainstream industry that has generated 2.4 bednights/pc nationally but 4.8 in the South East and 3.4 in the Centre compared with 1.8 in the South, 1.6 in the South West, 1.5 in Bucharest and 1.3 in the North East (Table 1). The regions can be located on Figure 1 which also shows the counties and highlights the Carpathian region that offers the best ecological resources (referred to below) and enjoys the support of a government agency dedicated to assisting the more marginal areas with agricultural development and pluriactivity including rural and ecological tourism.

\section{Some elements \\ of alternative tourism}

MONUMENTS are now a priority for conservation and cultural tourism is being boosted by the UNDP 'Beautiful Romania' programme, with the Ministry of Culture \& Religious Affairs financing conservation in Alba Iulia, Brăila, Constanța, 
Table 1 Tourism by regions in 2003

\begin{tabular}{|c|c|c|c|c|c|c|c|c|c|c|}
\hline Region & A & B & C & D & E & $\mathbf{F}$ & G & $\mathrm{H}$ & I & $J$ \\
\hline Bucharest & 3295.8 & 1.48 & 1183.9 & 0.53 & 35.9 & 2.0 & 697.5 & 0.31 & 58.9 & 2.0 \\
\hline Centre & 8515.5 & 3.38 & 2424.3 & 0.96 & 28.5 & 2.9 & 453.0 & 0.18 & 18.7 & 2.2 \\
\hline North-East & 4963.4 & 1.35 & 1450.4 & 0.39 & 29.2 & 2.6 & 178.5 & 0.05 & 12.3 & 1.9 \\
\hline North-West & 6341.6 & 2.31 & 2251.0 & 0.82 & 35.5 & 3.5 & 279.3 & 0.10 & 12.4 & 2.2 \\
\hline South & 5932.8 & 1.76 & 1704.0 & 0.50 & 28.7 & 2.0 & 253.5 & 0.07 & 14.9 & 3.4 \\
\hline South-East & 13629.6 & 4.79 & 5153.5 & 1.81 & 37.8 & 5.1 & 593.4 & 0.21 & 11.5 & 5.3 \\
\hline South-West & 3701.3 & 1.59 & 1643.2 & 0.70 & 44.4 & 5.1 & 45.7 & 0.02 & 2.8 & 2.2 \\
\hline West & 5252.2 & 2.68 & 2034.8 & 1.04 & 38.7 & 3.9 & 264.5 & 0.13 & 13.0 & 2.1 \\
\hline Total & 51632.3 & 2.38 & 17844.6 & 0.82 & 34.6 & 3.5 & 2765.5 & 0.13 & 18.3 & 2.5 \\
\hline
\end{tabular}

A Capacity (th.bednights); B Ditto per capita; C Utilisation (th.bednights); D Ditto per capita; $\mathbf{E}$ Utilisation rate (usage as a percentage of capacity); $\mathbf{F}$ Average length of stay; $\mathbf{G}$ Overnights by foreigners (th); $\mathbf{H}$ Ditto per capita; I Foreigner overnights as a percentage of the total; J Average length of stay for foreigners

Source: Statistical Yearbooks

Focşani Iaşi, Mediaş, Sibiu, Sighişoara and Târgovişte in 2003. Other projects include the historic square in Baia Mare and a $\$ 1.1 \mathrm{mln}$ programme to restore the Arad fortress; along with a $\$ 5.0 \mathrm{mln}$ World Bank loan to restore Brancuşi sculptures in Târgu Jiu. Currently there is much interest in the Dacian citadels in the OrăştieŞureanu Mountains, prominent among the Romanian historical monuments included in UNESCO's world patrimony list (along with Bănița and Piatra Roşie). A $€ 7.2 \mathrm{mln}$ Phare project will conserve the citadels and integrate them into the tourist circuit. In addition to multidisciplinary study involving ministries and the Romanian Academy, the local authority (Hunedoara County Council) has a role in controlling the use of metal detectors - widely used in the search for gold. A natural park would now be an appropriate designation for this area and help control the construction of holiday villas within $500 \mathrm{~m}$ of protective perimeters extending over 127ha at Blidaru, 116ha at Costeşti and 332ha at Sarmizegetusa Regia (332ha) - all included in the UNESCO list. Other monuments of this period are being conserved e.g. the Daco-Roman settlement at Aiud with a subsequent earthwork fortification and a later fourteenth century citadel (excavated during 1974-7) with stonewalls, bastions and towers added later. Some Roman sites were safeguarded under communism e.g. the remains of Trajan's bridge at DrobetaTurnu Severin - of great interest to Romanians - were protected by a concrete wall when the Iron Gates dam was built. Reference should also be made to a wealth of historical buildings including Medieval monasteries and Early Modern churches (Plate 1) as well as fine vernacular architecture (Plate 2). At the same time other ethnic interests require due recognition (Light \& Dumbraveanu-Andone 1997). Hence the exhibition on disappearing assets and values at the National Szeklers' Museum in
Sf.Gheorghe which attracted interest by the Transylvania Trust, the Historic Monument Restorers of Transylvania and the 'Kopeckzi Sebestyen Jozsef' Monument Protection Association in 2000 with a view to interdisciplinary, inter-ethnic and inter-cultural dialogue. A remarkable restoration involves the Count Kalnoky mansion at Micloşoara (Baraolt): a border fortress that became a 16th century hunting lodge and is now restored for weekend dinner parties, along with 19th century guesthouses retaining antique furniture and traditional wood stoves (though bathrooms respect western standards of comfort!).

Saxon Monuments are another major concern in the light of the rapidly dwindling German population and the inappropriate transformation of the German heritage in Mărginimea Sibiului. The historic centre of Sălişte has been damaged through plaster and stucco being scraped off the houses and replaced by 'Oltenian elements' introduced by new Roma inhabitants. Considerable interest in the conservation of the area was shown at the Berlin International Tourism Fair (2002) and rural tourism is now established at Răşinari, Sălişte and elsewhere. Money has been going into the rehabilitation of tourism in Sibiu county since 1998. This has impacted on the Medieval architecture of Sibiu itself (reduced to a precarious state, requiring international help) but also the rural citadel churches of the thirteenth-fifteenth centuries (Alma Vii, Biertan, Câlnic, Moşna and Pelişor. There has been help from the CoE, World Bank and World Monuments Fund, while a Romanian Cultural Foundation programme for Saxon Villages is being supported supported by Britain's Prince Charles and the Mihai Eminescu Trust (Plate 3). An interest in communities as well as buildings has highlighted organic farming (with the help over producer licences and mar-

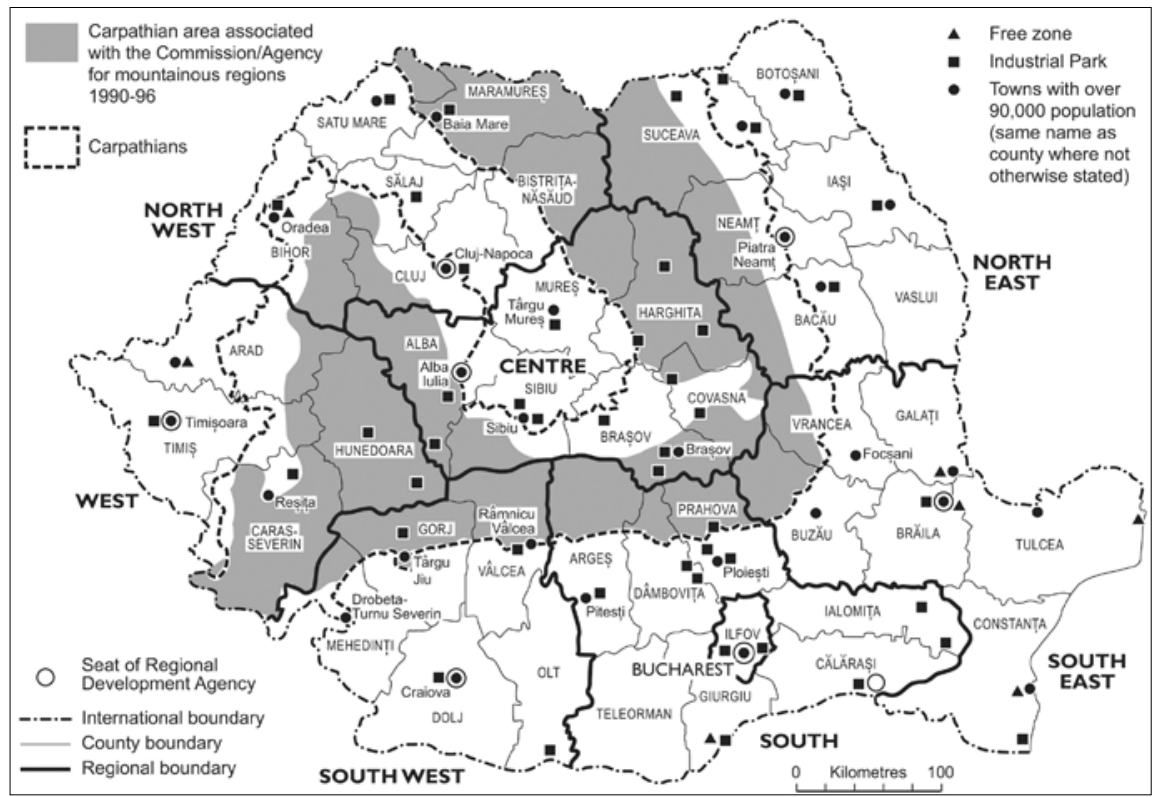

Figure 1 The regions and counties of Romania; also showing the Carpathians and the area of responsibility for the Agency for the Mountain Zones 


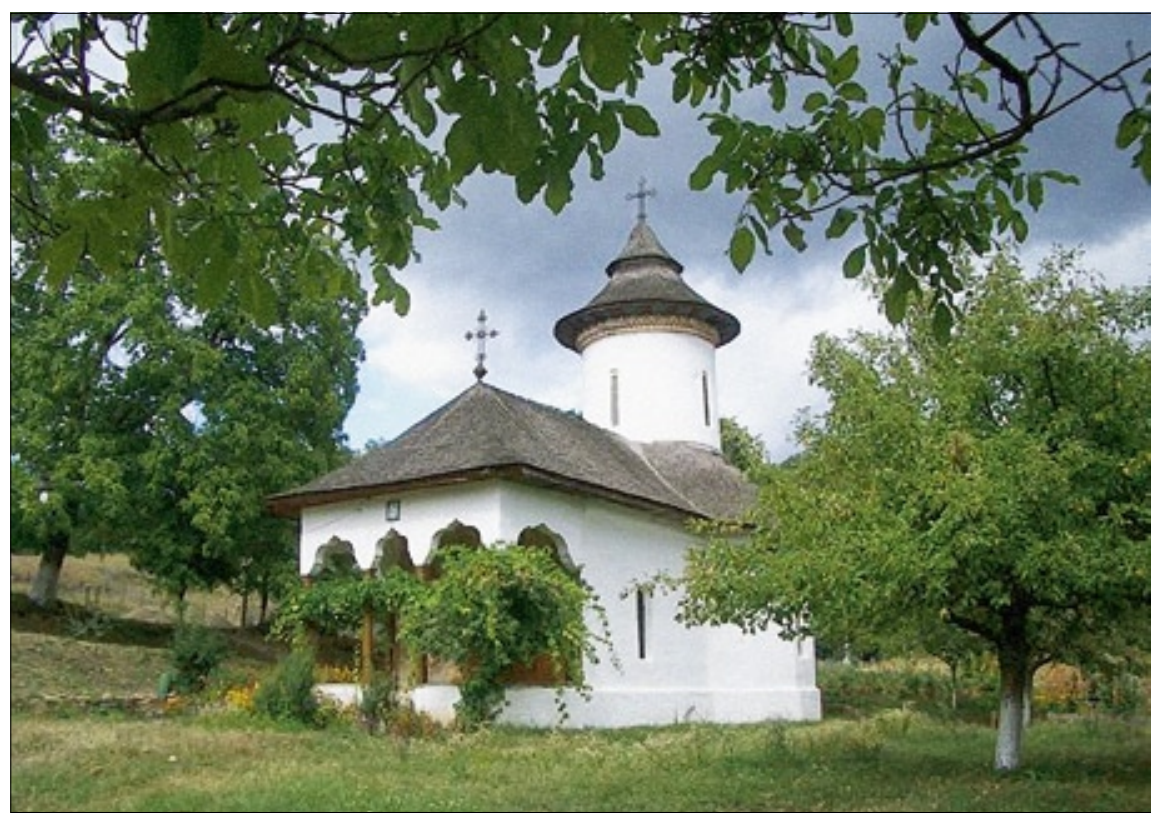

Plate 1 Cârnu Monastery in the upper Buzău valley (Buzau county)

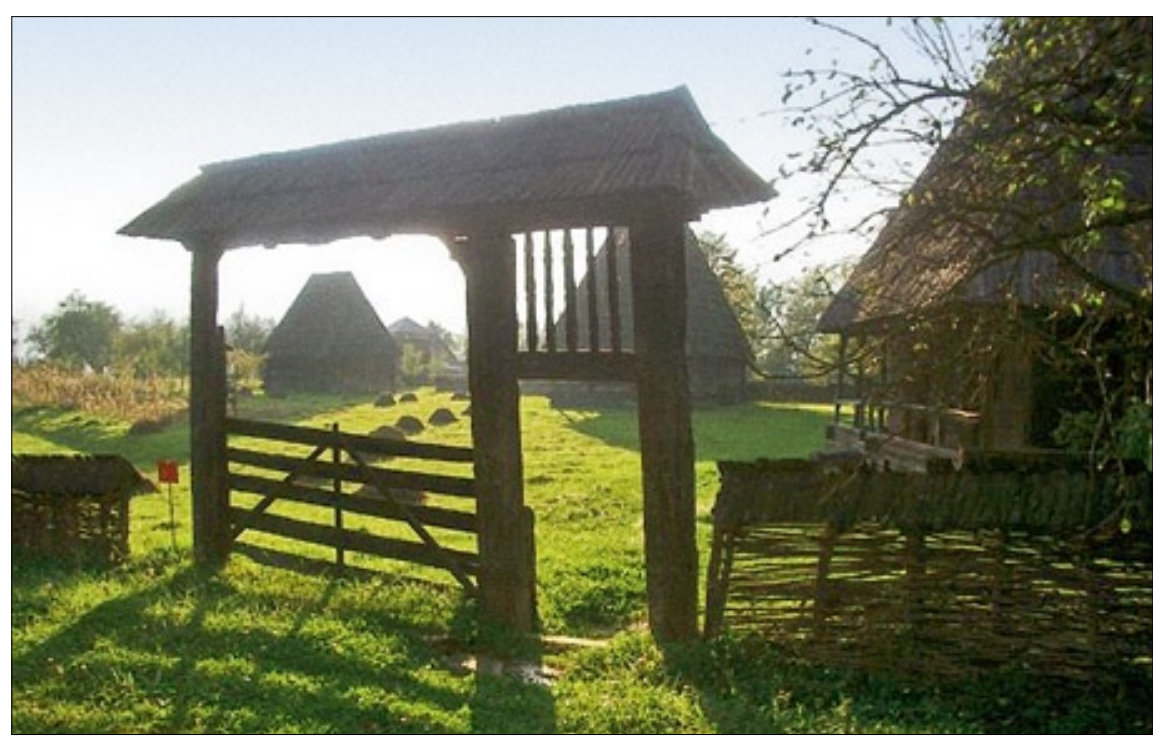

Plate 2 A typical wooden gateway commonly used at the entrance to houses in the Iza and Vişeu valleys (Maramureş county) Trim slightly at top and right side

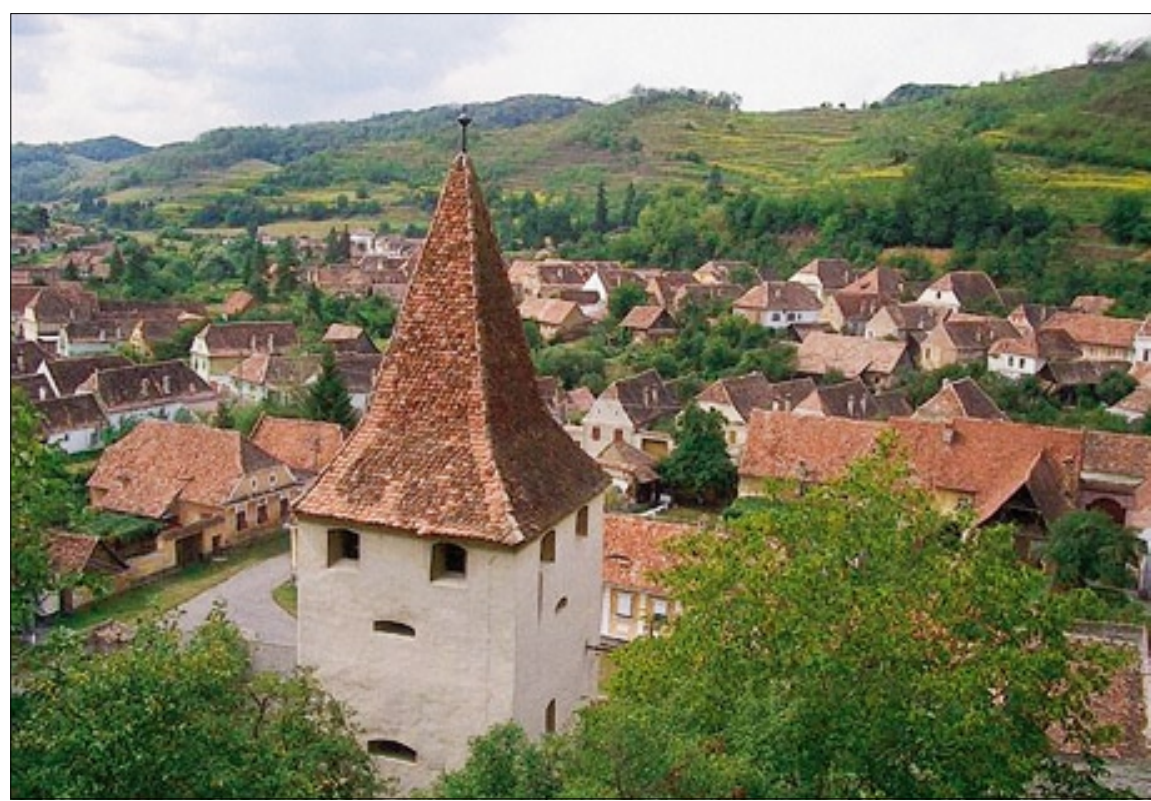

Plate 3 Persistence of German architecture in the village of Biertan near Sighişoara (Sibiu county) kets) and rural tourism, with British specialists working in ten villages in 2002. It is planned to use some Saxon churches for theatre shows e.g. Cisnădioara, Câlnic and the thirteenth century mayor's house in Sibiu. At Sighişoara, Medieval tourism was being promoted in 1998 through a Centre for Development \& Promotion of Historical Tourism by Mureș Local Development Corporation with money from Phare (which is also interested in SMEs and upgrading rural environment). Restoration of monuments has followed and the local tourist circuit enhanced. Phare has also helped revamp the cultural-historical monuments in the Braşov area linked with defended settlements built after the Tartar invasion 1241 (contrasting with Romanian dispersed system).

Industrial Archaeology opportunities are very extensive in view of the pace of modernisation and retooling since 1989. Only a very small amount of historic equipment can be rescued. But several narrow-gauge railways have been retained (Sibiu-Agnita, Târgu Mureş-Band and Turda-Abrud) while a heritage tramway in Iași features an old vehicle with 18 wooden seats brought out from the obscurity of the depot in 1998 to operate at weekends with a refreshment service. Sadly however a highly-desirable project to restore the Covasna-Comandău forest railway, including a unique inclined plane is threatened by the bankruptcy of the Brafor logging company and restitution claims from people who purchased the timber company (Erdelyi Erdoipari) from Jewish Groedel family in 1944 prior to nationalisaton - although other systems still opertate commercially at Moldovița and Vişeu de Sus. In Caraş-Severin there is local interest is an iron-road ('drumul fierului') project based on the historic metallurgical industry initiative at Reşiţa, Anina and a scatter of other locations (Hillinger et al. 2001; Olaru et al. 2001). Following the experience with the Kraków salt mine in Poland, there are proposals for the Bocşa-Ocna de Fier-Dognecea area to maintain artificial lakes formerly needed for ore processing and the former Dognecea-Ocna de Fier underground transport passage. At Ocna de Fier, where there is already a private collection of aesthetic rocks, the local authority is looking for suitable properties that could be redeveloped for tourism e.g. the former Danila mine administrative building. Reşița already has a museum for the 'montan' economy and a steam locomotive collection while Anina has its coal mining vestiges and a remarkable mountain railway (dubbed the 'Romanian Semmering') to Oravița. Industrial archaeology blends with a religious profile augmented by a historic religious art collection in Reşița and Bocşa's Sf.Ilie de la Izvor mon- 
astery consecrated at the beginning of the century near a spring where miner Axente Perian regained his sight. There is also ethnography and folk architecture arising from the indigenous population diversified by Habsburg colonisation (Sabiel 200o); wildlife and fishing; winter sports established on Semenic and also at Poiana Mărului and Muntele Mic, with plans for cable transport between the latter two. New rural tourism accommodation is available at the Briza Munteliu guesthouse at Gărâna organised as a family association on the Austrian model; surrounded by fir-spruce-beech woods and related fauna with Semenic Mountain and the lakes of the Bahlui hydropower complex nearby lakes. Protected areas on Semenic, the Caraş Gorges and the Iron Gates Natural Park round off this complementary profile with the management of habitats to safeguard rare species like the Hermann turtle, poisonous viper, black stork, dwarf cormorant and dwarf falcon - thanks to EU finance (€o.4mln during 2001-4) and coordination by Bucharest University and an advisory council.

GASTRONOMY is another area of opportunity. Caraş-Severin CC organised a plum brandy festival at Băile Herculane in 1998 (promoting renowned brandies from Armeniş, Brebu, Soceni and Teregova), equivalent to the beer festival in Timişoara. However most efforts in this field have gone into wine, with a start provided by the $\mathrm{Mu}$ seum of Vine \& Fruit Growing at Goleşti, close to the Ştefăneşti-Argeş vineyards. It started in 1966 on 1oha site (alongside the Goleşti manor declared a museum in 1958) with a grape-growers house from Glăvile near Drăgăşani and a fruit grower's house from Davideşti near Vultureşti in Muscel. Now there are 25 houses, including a cellar from Valea Mare (Dâmbovița) dating to 1707 and a rural tavern of 1860 from Poseşti (Prahova), in addition to wine-making equipment and the surrounding vineyards and orchards. Now, with the wine industry completely privatised, the tourist authorities under Minister Dan decided to classify quality wine cellars (under a scheme of one/five-glasses!) with a pilot project involving the Prahova CC, the ministry and wine cellar administrations with special funding (15bln.lei) to surfacing local roads connecting the best cellars: Tohani (Gura Vadului) with 1,30oha of vineyards associated with Prince Nicholas (brother of Carol II) and his restored manor house; the Belu mansion and Jercali monastery at Urlați; the Cantacuzino mansion at Filipeşti; and Valea Călugărească with the mansion houses of Matache and Secui. A national 'Romania: Land of Wine' ('Țara Vinelor') programme has now been built around 30 cellars including eight in Vran- cea and Galați (including Costeşti, Dealul Bujorului, Nicoreşti, Odobeşti, Panciu, Paradis and Smulți), seven in Bucharest, Argeş and Prahova, four in Constanța and Tulcea (including Basarabi, Medgidia and Murfatlar) as well as Transylvania and Banat (e.g. Jidvei and Recaş), and two each in Iaşi (including Cotnari) and Oltenia. In Vrancea, wine cellars from the Ştefan cel Mare period (referred to in a document of 1700) were discovered at Panciu in 1952: the system was extended under communism and 3.omln bottles of Panciu champagne are currently stored - the product of Veritas, the leading local champagne maker with 1,476ha of vineyards and exports to USA and Western Europe. And the nineteenth century landowner villa ('conac boieresc') in vineyard country is becoming a hot property speculation. Meanwhile in Transylvania, Alba county's 'Drumul Vinului' association will launch a vineyard programme in based on demonstrations, tasting and accommodation at Cetatea de Baltă but including other vineyards in the Târnave area (Blaj, Jidvei, Sâncel, Şona and Valea Lungă) and the adjacent areas of Alba Iulia (Câlnic, Gârbova and Ighiu) and Ciumbrud-Aiud. Meanwhile visitors to the Lake Bicaz in Moldavia can take advantage of a floating restaurant serving local dishes.

ECOLOGY also requires some consideration in this chapter because much of tourism potential is tied up with landscapes that, although well-settled in view of dispersal of peasant agricultural practices, nevertheless retain a high biodiversity value especially in the mountains. Despite the ravages of mining (greatly intensified in the communist period) and the transformation of valleys by hydro installations, rural pollution levels were not excessive and tourism was broadly sustainable. The designation of nature reserves went ahead along with the creation of the first national park in 1935. Since 1989 however ecologists and conservationists have been able to publicise many local land use problems such as high grazing pressure or heavy deforestation - often exacerbated through individual actions in a new era of democracy and voluntarism including a widening of tourist activity. Given the threats to biodiversity the need arises for environmental education combined with legally-enforcable restraints e.g. in the case of national parks enlarged through many new designations in 1990, but without resources for effective management at a time of financial stringency and uncertainty over appropriate policies to strike a fair balance between conflicting interests.

A Pan-European Ecological Network (PEEN) has been advocated by foreign NGOs and increasingly by the EU accession agenda requiring more sophisticated planning procedures including EIA, much higher standards for water quality, pollution control and waste management and effective régimes for protected areas that are to be conceived in terms of continental protected area networks in line with ' $\mathrm{Eu}$ ropa 2000'. Moreover the European 'sustainability' concept is being handed down to new member states in terms of higher standards in agriculture and forestry in line with CAP 'second pillar' concepts of rural diversification and countryside management. The major NGOs like WWF naturally endorse these perspectives but argue for more radical policies in line with their criticisms of the EU as an organisation committed to growth. They argue that the high biodiversity values of ECE do not need reconstruction after the ravages of communism so much as safeguarding as a major European resource against threats arising from future development underpinned by heavier road traffic. They also see Europa 2000 as a stepping stone not only for a PEEN but also for ecoregionbased conservation that would treat mountain chains as a single units requiring coordination all the states involved instead of having protection restricted to local reserves and parks. Also Black Sea pollution crisis requires action in the relevant river drainage basins in terms of water purification, ecological rehabilitation and exploitation of tourism potentials e.g. at the picturesque lakeside settlement of Surduc near Timişoara. A unified approach to the Danube is emerging through the EU water directive that specifies planning at the level of river basins, with wast-water treatment (WWT) in all the large towns that currently pollute the river.

Meanwhile it was evident in the late 1990 s that prospects for greater coordination across the Carpathians were good. WWF became involved in a large carnivore initiative that is particularly relevant to the Carpathians in view of their relatively large numbers in this area. Indeed, bears, wolves and lynxes require large territories and use the Carpathian 'bridge' to connect habitats in the northern and southern parts of the continent. ENGOs are also getting together and one umbrella organisation has taken the name Carpathian Bridge ('Priashev'): an international association of public ecological organisations. The Environmental Partnership for Central Europe (EPCE) is also an important network for conservation and sustainable development. And in 1998 the European Centre for Nature Conservation - in cooperation with IUCN (World Conservation Union) and Polish Academy of Sciences' Institute of Nature Conservation - sent a message to the Arhus Ministerial 'Environment for Europe' Conference of 1998 and the Pan-European Biological \& Land- 


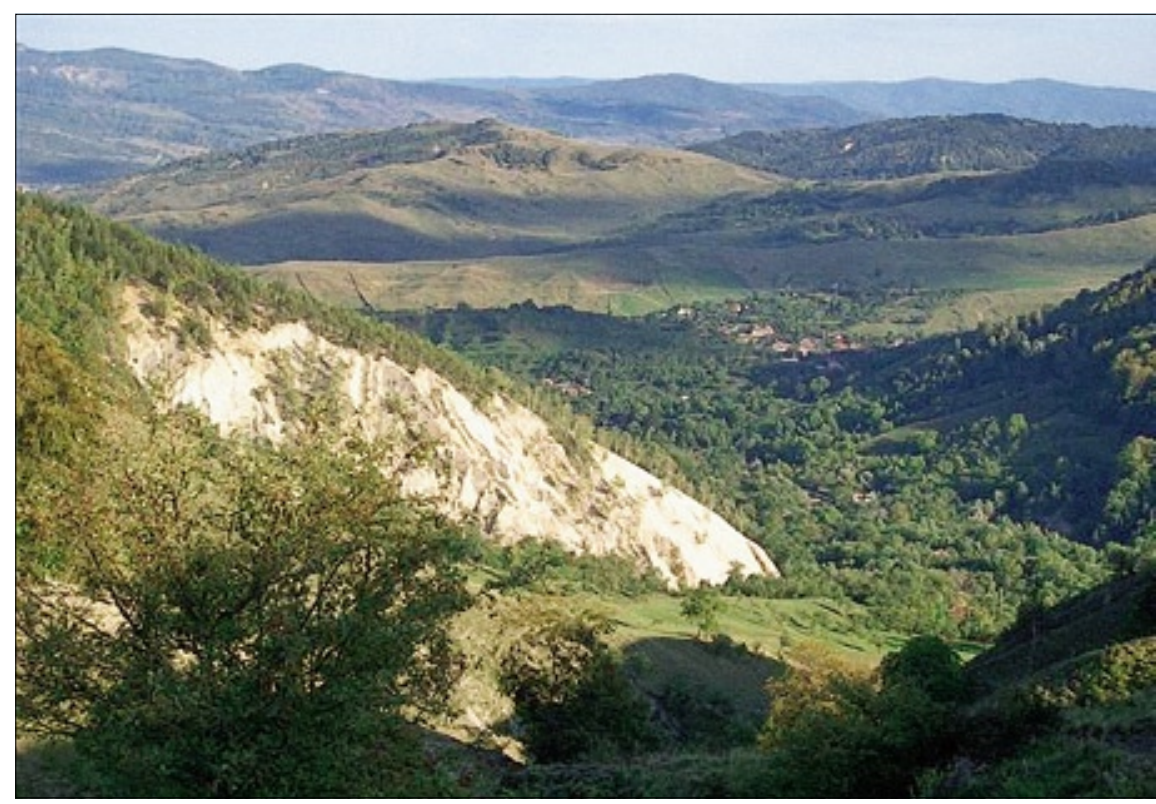

Plate 4 A Subcarpathian landscape with heavily-wooded hillsides around Muşcel village in the Pătârlagele atrea of Buzău county

scape Diversity Strategy, an inspiration of the CoE and UNEP geared to realisation of a PEEN (Bennett 1998). This 'Kraków Declaration' pointed out that "historic opportunities still exist in Central \& Eastern Europe to safeguard the remaining natural heritage" currently threatened by rapid landuse change in the face of heavy development pressure (Nowicki 1998, p.258). Motivated by a sense of shared responsibility fundamental to Europe's integration process, a PEEN was commended as a means of safeguarding the remaining natural and semi-natural areas, with research and monitoring for the Carpathians: also strengthened local capacities for conservation; and environmental education for local communities.

Threats to the Carpathians. While traditional peasant life has been broadly sustainable, the Carpathians are now confronted by a mix of threats in terms of urban-industrial development with significant levels of pollution (especially on account of coal-burning thermal power stations and chemical and metallurgical industries), tourist pressure (including hunting) and transport flows along the main European corridors. Development pressures in Romania are weaker, yet rural economies are less sustainable than before, given the illegal cutting of restituted forests and heavy grazing pressure by peasant farmers whose main source of income arises from the sale of livestock. WWF took the initiative in 1999 with a reconnaissance study that took account of all relevant expertise and involved contact with selected stakeholders and key actors in order to assess the biodiversity of the Carpathians in the light of current threats and conservation efforts. Priority Biodiversity Important Areas (BDIAs) have been identified, with particular weighting for habitats be- cause of their importance in finding centres of Carpathian endemism and also because of the good data coverage. These core areas are in many cases already protected in some way but in Romania the present system of national parks and protected landscape areas is relatively sparse and a proper management system is lacking. With approval of the programme at the Bucharest 'summit' of 2001 work is now proceeding on a long-term (10-15 year) ecoregional conservation plan with actions for the first five years. The Carpathica Convention signed in Kyiv in 2002 concerns a Carpathian Ecological Network - involving protected areas with 'good conservation and organisation' outside them - as part of PEEN. The EU Life-Nature Programme for 2003-4 now includes a project for repopulating Vrancea with bears, wolves and lynx in coexistence with the local population while in the Piatra Craiului, southwest of Braşov, a conservation project to safeguard the substantial large carniviore population has been in force for some years.

At the same time, there is a substantial rural population dependent on the natural resources and maintaining these fragile communities must be a complementary part of the vision (Plate 4). Any approach to conservation must recognise the universal demand for growth and higher living standards in all the countries involved. Hence the relevance of local projects for sustainable development in which NGOs (including those already networked through EPCE) will work with stakeholder groups within individual communities. There is no doubt that natural ecosystems in the Carpathians are under strong anthropological influence and large protected areas may pose as unacceptable barriers to development. Some traditional practices necessary to maintain grazing are- as may be threatened by local incomes e.g. in the Retezat where the local shepherds would like to be bought out. A strong push is coming from the EU taking the view that future pre-accession funding should reflect the status of agri-environmental schemes as a key policy instrument throughout the union. EU rural funding programme for accession countries (SAPARD) should be contingent on grass-roots' participation and on connections with protected areas networks and Natura 2000, although Romania has managed to evade this priority in large measure and agricultural-environmental projects are in their infancy.

\section{Rural and ecological tourism}

Although common enough in Western Europe through the British 'bed and breakfast' syndrome and the Continental 'gites', this is a relatively new branch for Romania. It was difficult to contemplate under communism with its focus on large state enterprise. But it now offers advantages as a route to rural diversification - labour-intensive rather than capital intensive - that is particularly attractive to country lovers and budget travellers seeking relatively cheap accommodation. However, if it is to become an important business, success depends on local attractions and the development of social capital within communities so that the business rests on a broad partnership rather than the enterprise of a few entrepreneurially-minded families. There are links with cultural tourism given the opportunity to live within traditional rural communities and also with ecotourism where travellers can take advantage of nature, including rare ecosystems and endangered or vulnerable species, and control of their impact upon it. This implies that not only is a certain 'capacity' required, but also a limit to the scale of development to achieve sustainability with regard to small, indigenous host communities and also sensitive environmental areas requiring careful design and management to minimise negative impacts.

EARLY INITIATIVES. Curiously, there was an initiative under communism that went beyond the provision of cooperative campsites, occasional motels and tolerance of second homes for well-connected families. In 1973 the Ministry of Tourism began an experiment in recognising 'tourist villages': two each in the counties of Braşov (Fundata and Şirnea), Dâmbovița (Lereşti and Rucăr) and Sibiu (Răşinari and Sibiel) and one each from Arad (Halmagiu), Gorj (Tismana), Maramureş (Bogdan Vodă), Suceava (Vatra Moldoviței) and Vâlcea (Vaideeni) shown in Figure 1. However the following year a new law came into force preventing foreigners from using of private accommodation, except in 
the case of very close family relationships. This meant that the relatively small numbers of foreign tourists travelling by car (the vast majority flew in on package tours) had little choice but to use hotels that were situated overwhelmingly in the towns. The law was very strictly enforced in Transylvania so much that Hungarians believed that its prime objective was to complicate their family contacts by forcing the more distant relatives into state accommodation, especially when a decree of 1976 abolishing restrictions and compulsory foreign currency exchange for Romanian emigres expressly excluded Hungarians. Further growth of tourism was then associated exclusively with the state sector, while rural planning became dominated by the drive to establish a network of agricultural-industrial centres with consolidation of the rural within restricted building perimeters. However, although neglected under communism, the ecological and ethnographical resources for rural tourism were largely preserved for posterity by unbalanced development that left much of the countryside in a time warp.

Under the transition rural tourism was favoured in several different quarters and initiatives were able to come together and produce a coherent programme. Noting the strength of rural tourism in the Polish Carpathians, the Commission (later National Agency) for the Mountainous Regions (NAMR) saw the business as fundamental to diversification in the mountains enabling the agricultural sector to respond to crisis. This dovetailed with the desire of the Ministry of Tourism to expand the business (with targets for an increase in domestic and foreign to $8.4 \mathrm{mln}$ and $7.2 \mathrm{mln}$ respectively in 2000) at a time when privatisation was too slow to generate investment to refurbish and expand the leading resorts. While large groups touring by bus would almost certainly continue to use urban hotels, rural tourism offered an opportunity for small groups and family parties from abroad to enjoy a wide choice of relatively inexpensive accommodation not available under communism. On the basis of a meeting of minds between the NAMR and the Tourism Ministry, the Federation for Mountain Development has encouraged farmers to diversify into rural tourism at a time when the Romanian media made much of the country's economic problems and the further downsizing in industry that was to be anticipated.

In 1992 the Ministry of Tourism suggested a range of criteria for the identification of tourist villages: picturesque and non-polluted countryside; traditional culture (with regard to costume, handicrafts, literature and music) along with special architectural styles in areas where villages or zones with traditional rural occupa- tions were still intact; and attractive natural landscape along with cultural and historical objectives that could form the basis of tourist itineraries; proximity to the railway and/or national road systems; and adequate local services (electricity, water, sewage and commercial facilities); social and economic resources to sustain a good standard of living; and qualified people to implement a local tourist programme in collaboration with tourist agents and operators (Plate 5). On this basis a start was made to select suitable villages and the list comprised Carpathian villages from the counties of Braşov (Bran), Caraş-Severin (Marga), Dâmbovița (Lerești), Maramureş (Călineşti), Sibiu (Sălişte and Sibiel) and Vâlcea (Vaideeni); as well as Sfântu Gheorghe from Tulcea county. It is not clear how these villages were selected. Detailed profiles were compiled through a survey document ('fisa') and it transpired that in Bran, Marga, Sălişte and Sibiel there were good socio-economic conditions (including infrastructure and services) and a receptive attitude to rural tourism on the part of both villagers and the local authority. The other four villages had deficiencies.

LEGISLATION became necessary to stimulate householder through fiscal concessions. As a result of legislation enacted in 1994 for the mountain zone, the Danube Delta and the Black Sea coast, approved farms and guesthouses (the latter having 3-20 rooms) providing quality services would enjoy ten years' profit tax exemption and are exemption from the regulations requiring permits from the electricity, water and sanitation authorities over design, health and safety matters. Moreover, prior- ity was allowed in the case of connections for electricity, gas, water and sewage - and also for a fixed telephone link (with charges for all these services at domestic rates); while land might be given by local councils and technical assistance provided by NAT and professional associations. However premises still had to be licensed to ensure minimum standards and a grading system of one/five-stars (now daisies) reflected the availability of modern toilet facilities, radio and TV, refrigerators and telephones (Mitrache et al. 1996). Efforts have been made to tackle the black market element evading quality control (which may account for up to $30 \%$ of the business) with further legislation in 2003 to deal with anomalies in the original law that seemed to encourage the illegal operations. And in order to improve quality it has been proposed that management courses should be mandatory for all operators of agrotouristical farms (ATFs).

The Tourism Research Institute thought that facilities in 8,500 rural households by 2000 would provide Romania with a niche in the market and spread the benefits of tourism more widely throughout the country without the need for heavy investment. The accommodation was needed especially in priority areas like Bran-Rucăr and Covasna and in wider zones comprising the Apuseni Mountains, the Eastern Carpathians (Bistrița-Năsăud, Neamț and Suceava) and the Black Sea coast including the Danube delta. On this basis, just over a thousand households were invited to apply for classification as units of rural tourism in 1995-6. These are spread somewhat unevenly over 20 of the counties including a portion of Carpathian mountain territory (although the first national catalogue

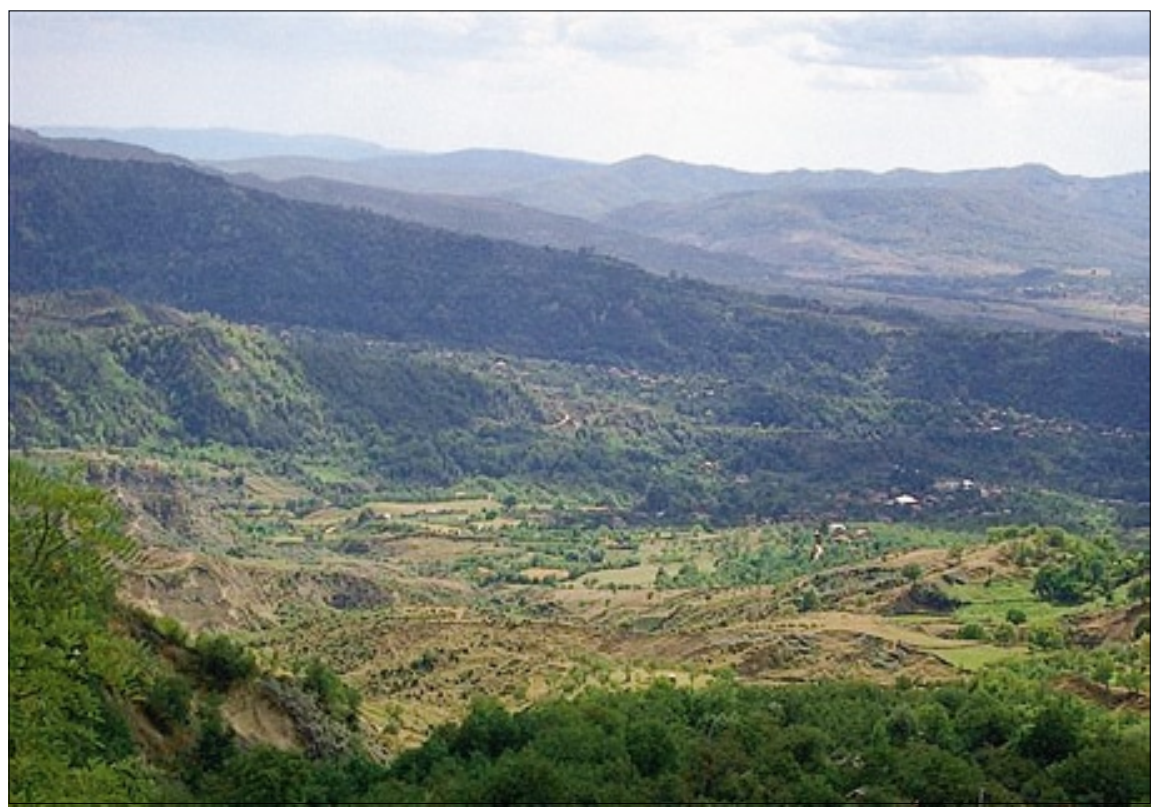

Plate 5 A diverse cultural landscape in the Pănătău valley near Pătârlagele in Buzău county. With varied lithology and inclination there is constant risk of landslides and a 'microlandschaft' reflects the varied potenials for land use and settlement 
contained no entries for the nine counties of Arad, Bihor, Caraş-Severin, Dâmbovița, Mureş, Neamț, Sălaj, Satu Mare and Timiş). Just over $60 \%$ of households accepted but with a substantial difference between the Curvature and Eastern Carpathians (above the average) and BanatOltenia and Western Carpathians where the response was much poorer. It is not clear why there should be such a clear contrast, although the strong tourist tradition in some high-scoring areas may explain a particularly positive attitude in some cases. The work of the local authority may also have been very important for a big growth of interest was reported in Vama (Suceava) in response to encouragement by local officials following a poor initial response. Specialist organisations have come to fore to stimulate rural tourism and provide input from the grass roots. In particular, a National Association of Rural Ecological \& Cultural Tourism (NARET - though ANTREC is the Romanian acronym) was formed in 1994 to promote of rural tourism throughout the country and identify barriers to development. Although it is based in Bucharest it developed in the area of Bran-Moeciu (near Braşov) out of the tourist accommodation agency Bran-Imex, managed by the Stoian family who are now prime movers in Antrec: Marilena Stoian being the organisation's chairperson while her mother, Maria Stoian, founded BranImex after arriving from Bucharest in 1990 as a second home owner. Antrec is therefore particularly strong in the Braşov area. Along with other NGOs like the Romanian Automobile Club, it collaborates with the Ministry of Tourism and Ministry of Agriculture with regard to rural tourism in the Carpathians.

INTERNATIONAL SUPPORT arises through NARET's affiliation to the Strasbourg-based European Federation of $\mathrm{Ru}$ ral Economic \& Cultural Tourism ('Eurogîtes'). This enabled Romania to draw on expertise from the 22 national and regional member associations, especially 'Gîtes de France' (France's national federation of rural tourism) which has 40 years experience in the business. Antrec acceded to the quality charter of Eurogites and Romanian addresses appeared in their catalogue from 1995. Romania's role in rural tourism was further highlighted by the holding of the 1997 Eurogîtes International Conference in Braşov and the election of Marilena Stoian as president of the organisation for the period 1997-9. Antrec also organised two events in 1996 that attracted an international entry thanks to its protocol of cooperation with Hungary's National Association for Rural Tourism. A competition for 'sarmale' (a delicacy consisting of cabbage rolls or vine leaves stuffed with meat and cornflour and eaten with horseradish during special events like New Year) was held at Praid (Harghita) in September, reciprocating an Hungarian hospitality in 1995, and a pie competition was held in Bacău later in the year. But equally important was the financial support for Romania's rural tourism. This came from individual countries such as the UK (providing economic advice under the KnowHow Fund) but most significant was Phare's support over marketing, regulatory frameworks and training. Phare has collaborated with Naret on the 'Promotion of Rural Tourism Programme' primarily intended to advertise Romanian rural tourism at exhibitions and fairs of both local and international importance. It has also established an effective rural tourism reservation network, produced brochures and organised workshops.

Opérations Villages Roumains (OVR) provided a parallel initiative originating as a concerted campaign mounted in Western Europe in 1988 to oppose Ceauşescu's 'sistematizare' by the development of twinning links. Around 1,500 such links were in existence in 1990, but after the revolution the emphasis shifted to development strategies and 'democratic workshops on agriculture and environment' held in ClujNapoca and Timişoara in 1991 revealed the opportunities in rural tourism as a new local dynamic (Moldovan \& Moldovan 1995). A total of 14 village pilots included four villages in the upper Arieş valley of Alba county: Albac, Arieşeni, Gârda de Sus and Scărişoara; three from Maramureş (Buciumi, Ieud and Vadu Izei), two from Harghita (Lăzarea and Chileni); and one each from Bistrița-Năsăud (Lunca Ilvei), Braşov (Şoarş), Mureş (Ceuaşu de Câmpie), Sibiu (Sebeşu de Sus) and Suceava (Vama) (Plate 6). In most cases an association developed

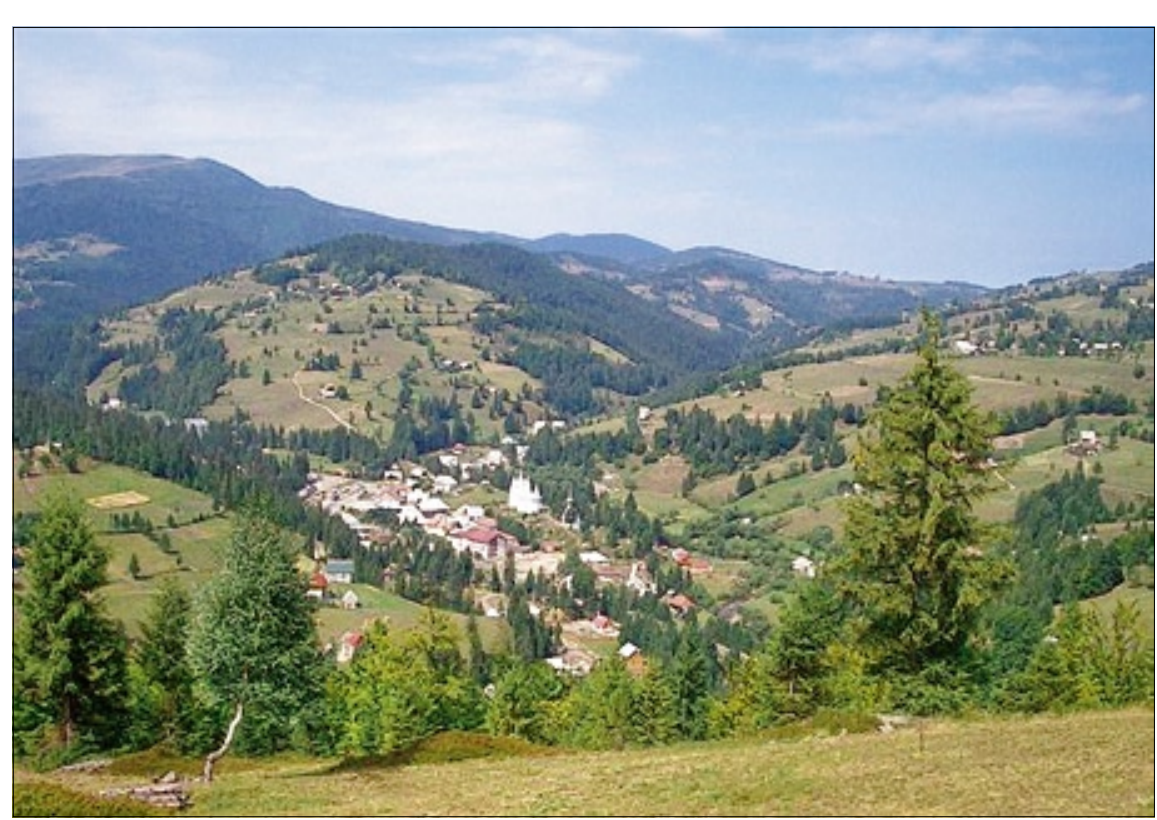

Plate 6 The village of Arieşeni (Alba county) with the ski slopes of Vârtop in the distance during 1992-3 and 1994 was the first year of activity: about a thousand bed-nights were secured and it appeared that the scheme might extend to other parts of the country with Phare support and other forms of assistance. 'Fondation Rurale Roumaine' helped these local projects by linking Timişoara University of Agricultural Sciences with Fédération Nationale des Foyers Ruraux (France), Fondation Rurale de Wallonie (Belgium) and L'Institut Européen d'Écologie (Metz). There was also help from the French Ministry of Foreign Affairs and Balgium's Wallonie Region over local coordination and autonomy involving development plans, exchanges of information and experience, resource exploitation and representation on public bodies (Ureche \& Ureche 1997).

Phare continued to play a key role through provision of €0.9omln towards the cost of a promotion and development programme to run from 1994 to 1997. There was a promotion programme leading to the first Naret catalogue with around 1,00o addresses, a computerised reservation system and information centres in four zones. Also a development programme, including infrastructure and training, was handled by OVR in four zones: the Arieş valley (Alba), Bran-Rucăr (Braşov/ Dâmbovița), Vadu Izei (Maramureş) and Vama (Suceava). This included a number of micro-projects including efforts to stimulate local crafts concerned with wood, embroidery and egg painting. Each village or group produced information describing the local facilities and opportunities so that a complete pack (covering all the pilot projects) displayed a wide diversity of attractions: landscapes, woodlands and other aspects of flora and fauna, agricultural systems, medicinal plants and mineral waters, winter sports, unusual transport 
facilities (forest roads and railways), historic buildings (castles, monasteries), museums and ethnography: including architecture, handicrafts, dances, festivals and other traditions (Wortthelet 1997). In each case there was a link with a village in Belgium (or another West European country) to help with external marketing: for example Vadu Izei was paired with the Belgian village of Brain le Compe. Annual inspections were made to check different aspects of the tourist product offered by individual households. The project demonstrated that rural tourism could be an instrument in the service of local development. For a time the European Centre for Eco-Agro Tourism (ECEAT), based in Amsterdam, was active in pioneering a network in Alba, Harghita, Mureş and Suceava coordinated by the Focus EcoCenter in Târgu Mureş.

Other Initiatives included an American organisation worked with Prahova County Agricultural Consulting Office to stimulate agrotourism for rural development in the Doftana valley where 24 households formed a local association in 2000 . The duplication of NGOs was in some ways unfortunate in introducing an element of rivalry and tension, but this is indicative of a lively grass-roots interest. What is important is that Antrec and OVR together provide a viable base for cooperation with the EU's Phare programme for the region. Previously the NAMR initiated an agrotourism programme in Vatra Dornei in 1994 in a bid to stabilise the population and it was claimed that 2,00o peasants has become involved by 1996. A significant contribution has also been made by the UK-based Mihai Eminescu Trust (already referred to) that also arose out of efforts made (from 1987) to oppose Ceauşescu's draconian rural programme. The Trust has worked on the rural preservation and regeneration and has pioneered its 'whole village projects' in two areas: Mălâncrav (with Criț, Florești, Laslea and Roandola) and Viscri (with Buneşti, Meşendorf and Roadeş) starting in 1999 and 2000 respectively. Guesthouses are now available in Biertan, Cloașterf, Criț, Mălâncrav and Viscri with excellent local opportunities for walking and horseriding including a trackway connecting the two clusters between Mălâncrav and Meșendorf. The Trust has also gained the support of UNDP for the integrated development of Sighişoara and the Saxon villages.

\section{DEVELOPMENT OFTHENETWORK.}

Romanian sources quoted a total of 18,500 visitors for the NARET network in 1995, including 3,500 foreign tourists each staying six nights on average, with average tariff of $\$ 12.5 /$ night, indicating a total income of $\$ 280,300$ from foreigners. Most farms finished up with fewer than 200 visitors during the year (with almost all staying less than a week) although some of the larger guesthouses attracted up to 1,500 guests in a year. It was evident that the ATFs involved might generate $25-30 \%$ of their total income from tourism, with further benefits through market outlets for farm produce and cultural development through foreign languages, appreciation of West European lifestyles and breaks from the normal farm routine. Rising demand stimulated some local tour businesses, shops and handicraft workshops, with catering for special interests (mountain biking, sports, painting and photography) in addition to general sightseeing. But extra jobs fell largely to booking agencies, with a few positions in cleaning, maintenance, catering and bar work in the larger establishments. More income might be generated from souvenirs, guided tours and publications: arguably each locality requires a cluster of attractions to be selected and developed through local consultation and included in the marketing effort. Both NARET and OVR should perhaps give more attention to local organisations and promotion of endogenous local and regional 'self-reliant' development. However, the business was by no means evenly spread even among the 23 counties in which Naret was active by the end of 1996 . With only $11.4 \%$ percent of the Carpathian centres, Braşov county alone had $33.6 \%$ of the ATFs in 1998 , while Alba, Argeş, Bistrița-Năsăud, Cluj, Covasna, Harghita, Maramureş, Suceava and Vrancea accounted for another $67.6 \%$ of centres and $58.6 \%$ of ATFs; leaving Bacău, Buzău, Gorj, Hunedoara, Prahova, Sibiu and Vâlcea with only $21.8 \%$ of the centres and $7.8 \%$ of the ATFs. There is still strong polarisation although more activity is now evident in Gorj and Vâlcea; also in Bihor, Dâmbovița, Mehedinți, Mureş and Neamț as well as several counties away from the Carpathians (Constanța, Dolj, Galați and Iaşi), including the Bucharest-Ilfov area with houses in Mogoşoaia, Otopeni and Snagov. The millennium programme featured Easter celebrations in Braşov/ Dâmbovița (Bran-Rucăr) and Maramureș (Botiza) but there were also special activities in two less prominent areas (Bihor and Hunedoara). Potential clearly varies according to the attractiveness of the cultural landscape, the scope for recreational activities and the degree of accessibility; also proximity to large cities. Thus, it is widely appreciated that the Bran-Rucăr corridor is a zone of particular opportunity.

The target (announced in 1996) was for accommodation in 8,500 rural households by 2000 , but this has proved wildly optimistic with the present figure of only 2,500 reduced to some 577 (in 202 localities) in terms of ATFs that have computers and internet access enabling them to enter the electronic database and provides a 'quali- ty' network that was one of the organisations early aims. Most locations have only a single ATF but clusters of 5-10 appear in Alba (Arieşeni and Gârda), Braşov (Poiana Mărului and Săcele), Gorj (Tismana), Harghita (Praid), Maramureș (Botiza, Rozavlea and Sălistea de Sus), Mehedinți (Dubova), Neamț (Viişoara), Prahova (Cheia), Sibiu (Sibiel), Suceava (Vama), Tulcea (Crişan) and Vrancea (Focşani). Higher numbers are found only in Ponoarele (Mehedinți) and Rucăr (Dâmbovița) with 12 each, Lepşa (Vrancea) with 16, Albac and Rimetea (Alba) with 17 each and most exceptionally the Bran and Moeciu areas of Brassov with 39 and 57 respectively. On this limited basis the Centre is the leading region with 55 locations and 258 ATFs, with a broad equality between the North East (32 and 61), North West (37 and 71), South East (34 and 78) and South West (26 and 63). The South (including Ilfov) follows (17 and 42) while the West has only a token respresentation through four pensions located in two Hunedoara villages. In Table 2 an attempt is made to integrate rural tourism into the pattern of larger resorts. It combines locations into groups that were prominent in the first catalogue: Bran-Moeciu (225 ATFs) and a group of others with 20-50 each - Arieşeni, Bargau Valley, Dorna, Iza Valley, Lazarea, Praid, Sâncraiu and Vama - and others that have developed recently with a cluster of ATFs on the current electronic database: LepşaTulnici, Ponoarele, Rimetea and Rucăr. It would be interesting to combine this material with mountain chalets and other dispersed tourist accommodation but the data for this is not readily available.

Stimulative Measures to increase demand include a continuing programme of special promotions e.g. the 'Holidays in the Countryside' programme, offering an attractively-priced package for five nights at ATFs in 40 localities in 16 counties. Special five-night tariffs have been offered in June at $0.95 \mathrm{mln}$ lei for two-daisies and 1.05 for three. There are also fairs and festivals (many with a gastronomic focus concerned largely, as before, with 'sarmale', pies or brandies). Publicity through CD was launched at the Rural Tourism Fair in 1997 while Naret was also involved in a seminar valorising the Carpathians (hosted by International Tourism Fair of Romania) in connection with the 2002 International Year of the Mountains. There have been efforts to stimulate interest abroad through Naret representatives in Chicago and Rome, while marketing in the USA has used the websites of American travel companies to advertise 100 ATFs from Braşov, Maramureş, Neamț, Suceava and Vâlcea in 1999. Maramureş carpenters - erecting traditional gateways - attended the Smithsonian Folklife Festival in 1999. Meanwhile, 
Table 2 Tourist resorts

\begin{tabular}{|c|c|c|c|c|c|c|}
\hline \multirow{2}{*}{ Region } & \multicolumn{5}{|c|}{ Resorts by category } & \multirow{2}{*}{$\begin{array}{c}\text { Resorts of national importance by name (category 'd' except where } \\
\text { otherwise stated }\end{array}$} \\
\hline & a & b & c & d & e & \\
\hline Centre & $\mathrm{O}$ & 8 & 33 & 27 & 5 & $\begin{array}{l}\text { Arieşeni(e),Băile Tuşnad, Bălvănyos, Bazna*, Borsec, Bran-Moeciu(e), Covasna, } \\
\text { Izvorul Mureşului(b), Lacu Roşu(b), Lazarea(e), Malnaş-Băi, Pârâul Rece(b), Păltiniş(b), } \\
\text { Poiana Braşov (b), Praid(e), Predeal(b), Rimetea(e), Rodbav, Sâncrăeni, Sovata, } \\
\text { Timişul de Sus(b), Vâlcele, Vârghis, Zizin }\end{array}$ \\
\hline North East & 0 & 5 & 12 & 8 & 2 & $\begin{array}{l}\text { Agapia (b), Bălțăteşti, Dorna (e), Durău (b), Şaru Dornei, Slănic-Moldova, Vama (e), } \\
\text { Vatra Dornei }\end{array}$ \\
\hline North West & 0 & 1 & 23 & 5 & 3 & $\begin{array}{l}\text { Băile Felix, Băile } 1 \text { Mai, Bârgău Valley(e), Borşa, Iza Valley(e), Sâncraiu(e), Sângeorz- } \\
\text { Băi, Săpânța, Stâna de Vale (b), Tinca }\end{array}$ \\
\hline South & 0 & 9 & 8 & 5 & 1 & $\begin{array}{l}\text { Amara*, Azuga(b), Breaza(b), Buşteni(b), Cheia(b), Poiana Tapului(b), Pucioasa, } \\
\text { Rucăr(e), Sinaia(b), Slănic }\end{array}$ \\
\hline South East & 15 & 0 & 8 & 1 & 1 & $\begin{array}{l}\text { Agigea, Balta Albă, Cap Aurora(a), Constanța(a), Costineşti(a), Eforie Nord(a)*, Eforie } \\
\text { Sud(a)*, Jupiter(a), Lepşa-Tulnici(e), Mamaia(a), Mangalia, Năvodari(a), Neptun(a)**, } \\
\text { Olimp(a), Sărata Monteoru, Saturn(a), Soveja, Techirghiol(a), Venus(a) }\end{array}$ \\
\hline South West & $\mathrm{O}$ & 2 & 9 & 2 & 1 & $\begin{array}{l}\text { Băile Govora, Băile Olănesti, Căciulata, Călimăneşti, Ocnele Mari, Ponoarele(e), } \\
\text { Rânca(b), Săcel, Voineasa(b) }\end{array}$ \\
\hline West & $\mathrm{O}$ & 6 & 10 & $\mathrm{O}$ & $\mathrm{O}$ & $\begin{array}{l}\text { Băile Herculane, Buziaş, Călacea, Crivaia(b), Geoagiu-Băi, Lipova, Moneasa, Muntele } \\
\text { Mic(b), Trei Ape(b), Vața de Jos }\end{array}$ \\
\hline Total & 15 & 31 & 103 & 48 & 13 & \\
\hline
\end{tabular}

a: seaside; b: mountain resorts; $\mathbf{c}$ : spas; $\mathbf{d}$ : ditto, coinciding with a mountain interest (seaside in the South East); e: agrotourism (national interest only and not including mountain chalets). Centres asterisked offer mud treatment Sources: Ghinea 1993 and NARET website

mprovement in quality has been sought through a national school of managerial training at Bran with teachers provided through collaboration with Dima Consulting, Transilvania Univerity, Bucharest Academy of Economic Studies, Bucharest Agricultural Institute, Ministry of Tourism, Krontour Travel Agency Braşov, Ana Hotels and Eurogîtes in 2001 alone. And in a bid to remain competitive standard tariffs have been abandoned so that in 2002 two-daisy establishments were making daily charges of $€ 8-15$ for a room and €812 per person for full board, rising to $€ 15-$ 30 and $€ 10-15$ respectively in the case of a three/four daisy classification. It is fortunate that many ATFs can be contracted electronically and there is great deal of material that can accessed on the Internet in addition to the NARET website www.antrec.ro (Ilieş \& Ilieş 2006).

The rural tourism offer has been critically examined by Benedek \& Dezsi (2006). Developing activities include the promotion of tourist itineraries linked with NARET accommodation e.g. in the Subcarpathians (featuring the Buzău mud volcanoes) and ecologically important areas like the Danube delta, Piatra Craiului and Retezat. Rural tourism is also being linked with hiking and cycling (the latter popular especially among Germans visiting Transylvania). Work with NAT aims to boost SMEs in rural tourism concerned with ecological-agricultural products; handicrafts and souvenirs; natural medicines and Gerovital clinics. Handicraft skills need preservation but also some marketing expertise, with help from USA Devel- opment Agency and an organisation 'Aid to Artisans' through a fair at the Bucharest Village Museum. Groups of craftsmen need to contribute 'standard' products and so generate large volumes appropriate for mail order firms distributing catalogues e.g. carpets, wooden bowls or painted eggs (while ceramics are problemetic for the American market because of the lead content in glazes that infringe US standards). Schools are being involved in ecological patrols, while school pupils' holiday facilities ('tabere') are being used more widely for tourism out of season, with job opportunities for retired teachers through a National Agency of School Camps \& Tourism. Antrec does not have funds to subsidise the creation of new ATFs, but the Romanian Fund for Social Development seeks to relieve poverty by financing projects in poor rural communities, while in 1999 NAT offered credits of up to $200 \mathrm{mln}$.lei for five years (up to half the investment value) at a preferential interest rate equal to inflation - to develop or update accommodation including entertainment facilities and infrastructure; and - specifically for rural tourism - BancPost credits have allowed some 50 existing pensions to develop and upgrade. Currently there are good opportunities through SAPARD. Finally, an ecotourism strategy was formulated in 2004 (by D.Dumbrăveanu) two years after UNO and the World Tourism Organisation had declared 2002 the 'Year of Ecotourism'.

AN OVERVIEW OF CARPATHIAN RURAL TOURISM (Ielenicz \& Dumbraveanu-Andone 1997; Petrea \& Patrea
2000; Turnock 1999) follows the National Agency for Tourism programme for 2001-4 in emphasising the potential for rural tourism in the Apuseni, Bucovina, submontane Oltenia, before giving rather more detail to other NAT priorities: Maramures, the national parks of Retezat and Piatra Craiului and also the Danube Delta Biosphere Reserve which lies outside the mountain region. Opportunities are very evident in the Apuseni through the OVR 'rețea turistică' in Alba's Arieş valley between Albac, Gârda de Sus and Arieşeni, but there are also good facilities in Cluj county along the Oradea road as far as Huedin and Ciucea and also in some of the villages to the south of this axis (Petrea 2004). While the valley slopes are thickly wooded the high platforms were cleared for agriculture through heavy population pressure in the early modern period, providing extensively panoramas across rolling meadowlands extending to $2,000 \mathrm{~m}$. Interest lies in the karst scenery featuring many caves among which the most remarkable is 'Ghețarul Scărişoara' at a height of $700 \mathrm{~m}$ where a 4,000 year old ice block survives in a great 'hall' within a cave system some $50 \mathrm{~m}$ below ground. The scope for 'adventure tourism' in remote has been demonstrated by Green Mountain Holidays promoted by a Belgian businessman. The domestic architecture of dispersed settlements - and a local cuisine that includes 'balmos' (pancakes made from flour or potato) - has been highlighted by refurbishment projects undertaken by the Open University of Nürnberg which has done much to promote ecotourism linked with Europe's natural habi- 
tats. With the cooperation from Albamont over signposting, the director of the Rural Foundation of Romania, Bernard Houliat, has launched 30 tourist intineraries to access isolated villages 'far from the maddening turmoil of modern civilisation'. The mining history is laid out through the gold museum in Brad (developing from an 1890 collection of mine flowers) and a collection of processing equipment at Roşia Montană where there is also access to Roman underground workings. But it is perhaps the wood-based economy that is allpervasive through local handicrafts and the domestic production of planks ('scânduri') marketed by lorry or cart in the surrounding lowlands. Damage through overcutting and pollution of rivers through the careless handling of sawdust points to the importance of income from tourism to limit dependence on the forests whether it be for timber or secondary products like mushrooms and berries. At the same time tourism has its dangers evident in the rash of second homes in the Someş Cald valley, the growing popularity of caving and the threat to speleological patrimony from souvenir hunters, the threat to forests from piste development for winter sports (rather than cross-country skiing) (Buza et al. 2001; Surd \& Turnock 2000).

Bucovina attracted foundation work by OVR in Vama and the NARET catalogue now shows that the business is well-established in the Dorna area (Dorna Arinilor, Dorna Cândrenilor, Poiana Stampei and Şarul Dornei) as well as Vatra Moldovițe in Suceava county. In this well-wooded country - sometimes known as 'Little Switzerland' and, complemented in the adjacent county of Neamț by scenic areas of Bicaz, Ceahlău and Durău - the potential lies first and foremost in the historical, religious and cultural value of the monasteries. In 2000 Philippe François stimulated interest from the French government, UN, UNESCO and EU for the concept 'The Natural \& Regional Park of Bucovina's Monasteries' as an international multi-cultural project, while further attention was generated in 2003 by an international 'Putna 500' programme for $\$ 30 \mathrm{mln}$ of spending on infrastructure to celebrate 500 years since the death of Ştefan cel Mare in 2004, a Medieval Moldavian prince who contributed substantially to the patrimony. Neamț also has its monasteries although (without the exterior frescoes that are a striking feature of many in Bucovina) giving rise to a growing 'ecumenical tourism' at Agapia and Varartec. Meanwhile Dorna and Rarău offer a good basis for mountain tourism with conventional activities supplemented by rafting on the Bistrița, organised once again (since 2003) from Vatra Dornei on the challenging Broşteni-Crucea and Zugreni sections. Ethnography - again grounded in a distinct domestic architecture - is catered for by the Bucovina Ethnographic Museum in Suceava, dating to the 1970 s with a 6.0 ha open-air section containing representative houses and workshops (also by local house museums at Bilca and Solca). The economic history is bound up with agriculture and forestry with mining relatively restricted. The local tradition of egg painting has been assisted through an interesting initiative by the British Embassy help - following the initial coordination by a British language/literature specialist based in Suceava's Ştefan cel Mare University - through creating a Bucovina Egg Painters' Association linked by computer with potential purchasers abroad and so increase sales beyond the local market.

Oltenia. There is also considerable potential lying much closer to Bucharest with a cultural-religious basis provided by the Vâlcea monasteries such as Arnota, Bistrita, Cozia, Govora and Horezu, not to mention the Râmnic Bishopric in Râmnicu Vâlcea dating to the seventeenthnineteenth centuries with walls painted by Gheorghe Tattarescu and Grigore Zugravu. Several monasteries offer accommodation while a network of ATFs has developed in 24 locations with four significant clusters: Dubova and Ponoarele (Mehedinți) as well as Novaci and Tismana (Gorj). Some are situated in isolated positions e.g. the Stroie family pension in a new building in the Olăneşti valley on land obtained from former cooperative farm immediately af ter the revolution. Rural tourism has previously been tied mainly to chalets in the Cozia, Lotru and Parâng Mountains (Vâlcea) - where conservation issues are much debated, especially with Cozia designated a national park (Ploaie \& Turnock 2001) and small resorts like Rânca and Voineasa where further growth is likely, especially at Rânca (1,60om) above Novaci where many new villas are now appearing and commercial investments are being made by companies from Gorj and surrounding areas that could make this resort the 'Pearl of the Parâng' especially if the road northwards to Sebeş is reconstructed. However a complementary ATF-based tourism can bring visitors closer to the local vernacular featuring Brâncovan arches and drinks comprising brandies, fruit juices and wines. Other historical perspectives arise through Roman camps including a reconstruction at Cozia and contemporary native fortresses such as Buridava. Ethnography is conserved through the Collection of Ethnography \& Folk Art at $\mathrm{Bu}$ joreni and the Wine Museum at Drăgăsani and through entertainment at traditional fairs such as Polovragi. Ceramics are still produced at Horezu where the 'Cocoşul de Hurez' or Hurez Cock festival attracts potters from all parts of the country. There are also carpet makers and furriers. And given the main roads running parallel to the mountain axis itineraries can easily extend from Vâlcea through Gorj to Dolj and Mehedinți with Naret publicity covering such themes as hunting and fishing, fortified manor houses and other historical themes such as banditry and witchcraft. Further west, rural tourism in Mehedinți has developed around Baia de Aramă (including the natural bridge of Ponoarele) and in the Danube defile (Cazanele Environmental Reservation). There is also developing cooperation over Subcarpathian tourism extending along the mountain axis easterns around the Carpathian 'bend' as far as Buzău and Vrancea.

\section{Major protected areas}

MARAMUREŞ BIOSPHERE RESERVE

(Dezsi et al. 1999) has seen much activity under OVR auspices at Vadu Izei on the edge of the town of Sighetul Marmației and villages further east along the Iza valley such as Botiza and Sălistea de Sus (Turnock 2002a; 2002b). The area also offers small hotels and a high-quality guesthouse run by nuns in a section of the new monastery of Bârsana. Accessibility in this frontier region has improved thanks to more open frontiers with Ukraine (including regular local rail services at Câmpulung and Valea Vişeului - as well as a new road bridge between Sighet and Slatina - which help Romanian communities 'stranded; north of the Tisa (Boar 1999; 2001). This is a well-forested area where wood-working is prominent tradition in addition to the modern factory-based sawmilling. When the $\mathrm{CoE}$ combined with the culture ministry over 'The European Roads of Wood' project - seeking the cooperation of governments and NGOs in a European organisation to preserve cultural patrimony represented by wood and revitalise traditional wood handicrafts in conjunction with museums and rural tourism networks - the first meeting of experts took place in Maramureş in 200o. The extensive use of finely-carved wood is evident not only in the housing but also in traditional industrial installations usually based on water power. In the Cosău valley where almost 100 installations existed in the early 20 th century only 28 were still working 1973 in Budeşti, Călineşti and Sârbi when interdisciplinary research started - and there are now fewer still because of decreasing self-sufficiency in the villages; although some rehabilitation is being supported by the Carpathian Euroregion as part of a programme for 'Peasant Technology: Heritage of Millennium III' (Plate 7). Wood carving skills are also well-demonstrated at Săpânța where Ioan Pătraş started making oak memorial crosses for the 


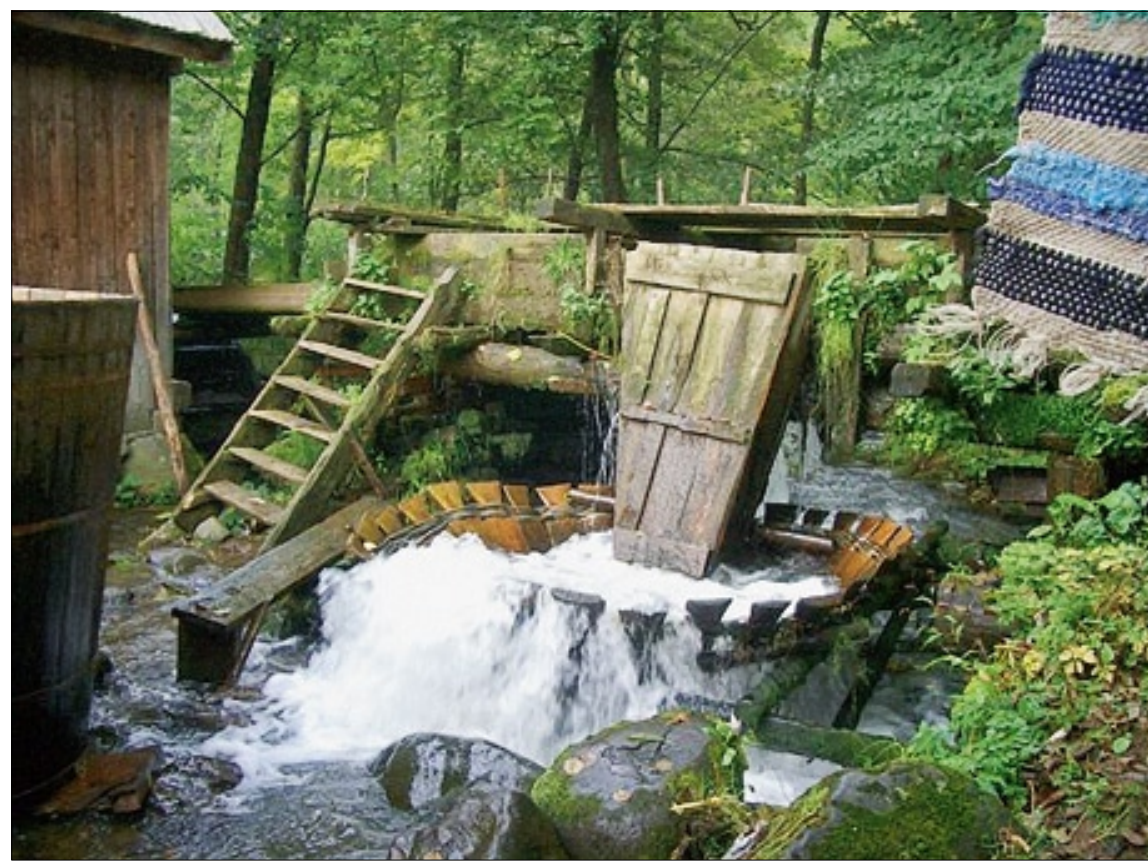

Plate 7 A fulling mill for washing blankets in the village of Budeşti (Maramureş county)

local churchyard in 1935: they were painted in blue and depicted episodes (frequently humorous) from the life of the deceased.

The tradition has been maintained by others since the death of Pătraş in 1977 and the whole cemetery has been restored thanks to the efforts of a former US ambassador James Rosapepe who monitored the work personally. Meanwhile local crafts extend to ceramics and textiles (including the use of vegetable dyes) while the folklore is rich in music and dance, with the wearing of masks a practice thought to originate in Geto-Dacian culture. These traditions are retained through 'Mara $\mathrm{Mu}$ sical: European Festival of Fiddle \& Countryside Music' initiated by Bernard Houliat with the support of Ministry of Culture and OVR as well as 'The Museum of the Romanian Peasant' in Bucharest. Except for the Baia Mare non-ferrous ores and the Sighet saltfield (Coştiui and Ocna Şugatag) mining is relatively recent, but traditional logging methods have been retained in the Vaser valley through the narrow-gauge forest railway, with steam traction supported by the 'Traditionszug für die Wassertalbahn' project which has financed the overhaul of several locomotives including an Orenstein \& Koppel engine of 1911 (Plate 8). Elsewhere there are opportunities to travel in road carriages or undertake a donkey safari as far as Prislop Pass and even the Bucovina monasteries. Nature conservation is proceeding along the frontier in the Romanian-Ukrainian Biosphere Reserve for the Maramureş Mountains and also in the Pietroşu Rodnei National Park where the Ecologist Society of Maramureş is spending $€ 400,000$ of European money to repopulate the mountains with the 'lammergeyer': a particularly valuable species of bearded vulture that disappeared from Romania some 70 years ago. Environmental hazards arise from heavy deforestation evident by the 1960s and 1970s and still a threat in some localities through the illegal operations of a 'forest mafia'. There are also problems through the over-exploitation of medicinal plants increasing in the 1970 .

RETEZAT NATIONAL PARK is relatively long-established and is a good example of a mountain area where tourism depends heavily on mountain chalets. As is thje case of the Piatra Craiului NP (see below) and Vânători-Neamț forest park management strategies are being developed with the help of non-reimbursable as the principal means of timber extraction finance from GEF $(\$ 5.5 \mathrm{mln})$, supplemented by $\$ 2.4 \mathrm{mln}$ from the Romanian government and $\$ 0.9 \mathrm{mln}$ from the NFA. The Retezat is a remote alpine region reserved for chamois hunting by the Hungarian Kendeffy family until land reform opened up the area to grazing in 1923. However there was sporadic logging from the 188 os with transport by floating on the Lăpuşnicul Mare assisted by water stored above wooden dams ('zătoni'). There was no proper restocking due to difficult working conditions and the scarcity of labour - indeed there was some burning to prevent regeneration in hayfields. Given the new threats and the wider appreciation of the area's biodiversity, a botanic reserve was set up in 1927 leading to the national park in 1935 $(13$, oooha). Grazing rights continued with some restrictions although forestry was controlled with limits to cutting for firewood and fencing and the main threats to woodland arose through fires (as in 1943 and 1946) and the avalanche 1994 in the Pietrele and Galeşul valleys. However the nationalisation of forests in 1948 allowed a unitary protection regime. The law of 2000 set new limits enclosing a much larger area of 38,047 ha - with an administration that began to function in that year.

This larger area was first proposed by the Academy's Biological Sciences Institute in 1993 to comprise an 'bsolutely protected area' of 9,503 ha and a buffer of 28,544 ha: a compromise between a larger area of 54,542 ha suggested by MWFEP in 1990 and a area even smaller than the existing limits preferred by the forestry authority concerned about future woodland exploitation and the difficulty of protecting grazing areas effectively. The Retezat was also

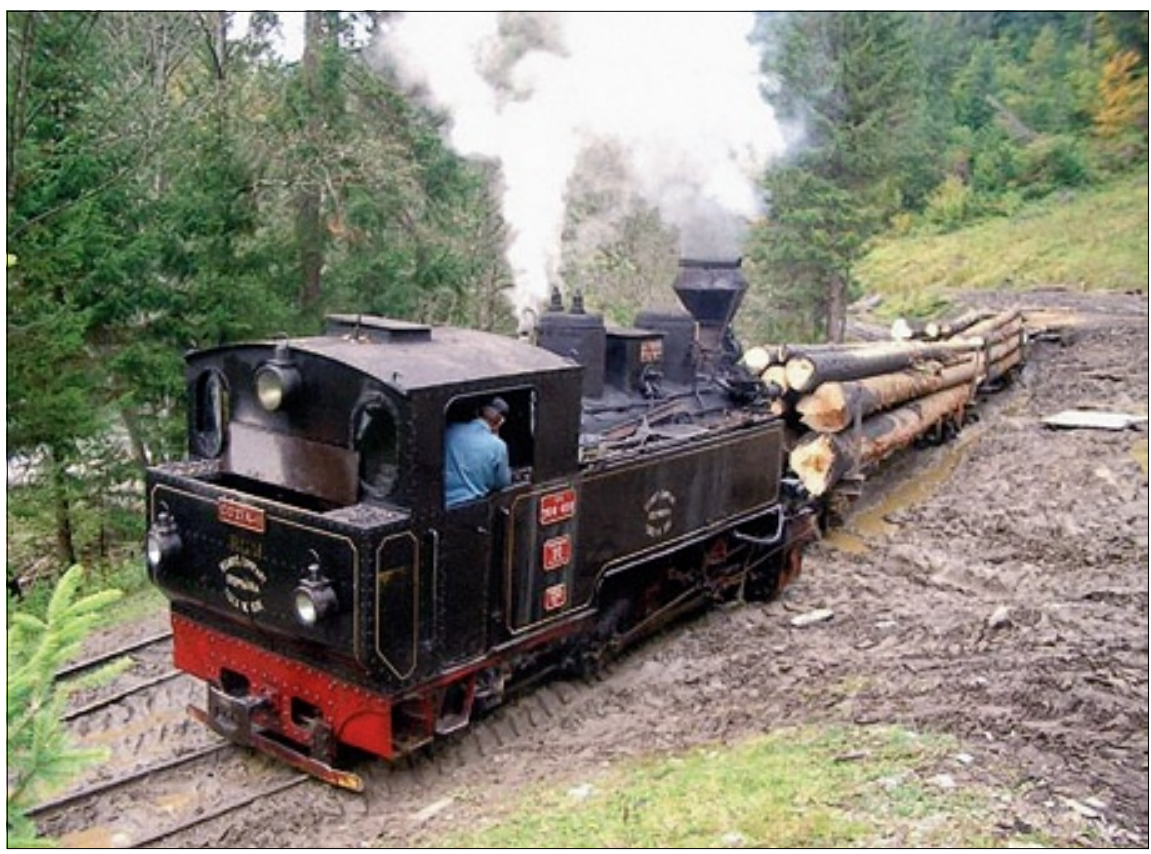

Plate 8 The forest railway in the Vaser valley above Vişeu de Sus (Maramureş county): one of only two systems surviving in a areas that was once use narrow-gauge railways 
established as a biosphere reserve in 1979 with an area of 20 ,oooha but the boundaries were never established officially and although the reserve is currently registered at 55,0ooha - with central (4,60oha), buffer $(20,000)$ and transition $(30,400)$ zones but there are still no legal boundaries and therefore the reserve does not extend effectively beyond the national park. The debate over boundaries is perhaps academic because the core of the park is a strictly protected area (where traditional pasturing - largely excluding sheep - is the only economic activity allowed) which is currently only slightly larger that the original park (within which a small area was set aside in 1955 as the 1,62 oha Gemenele Scientific Reserve where absolutely no grazing is allowed). The rest is a buffer zone that (hopefully) will be extended eventually through programmes of sustainable development covering at least the communes of Râu de Mori and Sălasu de Sus as well as the Câmpu lui Neag area (within the town of Uricani): this would increase the total area to 102, oooha (Figure 2)

Forest Management. 1.04th.ha of woodland within the park now belongs to communities as 'camposesorate' and 19.48th.ha of alpine grazings also belong to surrounding communities who use the Retezat for grazing, agriculture, fruit and wood, although pressure is moderated by the poor infrastructure (including a lack of information and modern communications), an ageing of the population less committed to traditional products, and a lack of both development funds and integrated sustainable development strategies (Plate 9). However, grazing is a major concern given the common rights held by 23

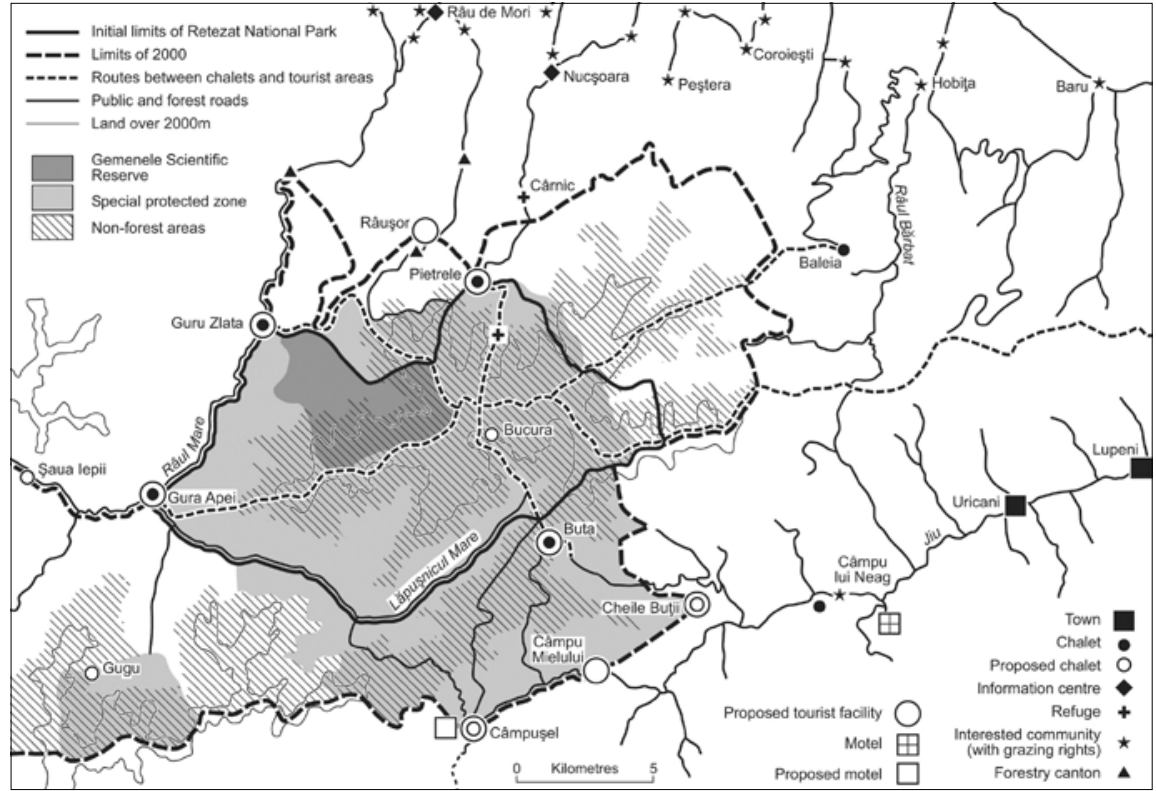

Figure 2 The Retezat showing proposed new tourist facilities

villages (eight communes): it is regulated by the local authorities (apart from a short period during 1986-90 when forestry district offices set precise limits that were generally respected) and there a tendency to overgraze through the 'contracting out' of pastures in the 1970 and again since 1990 with sheep allegedly brought in from as far afield as Hungary. It is now important to reestablish effective grazing limits through consultation and prevent further destruction of brushwoods comprising the Carpathian pine (Pinus mugho). There is also a need for unitary management to overcome the separate interests of (a) scientific work associated with the Romanian Academy's Commission for Natural Monuments; (b) forestry, along with hunting and fishing; (c) alpine grazings administered by lo-

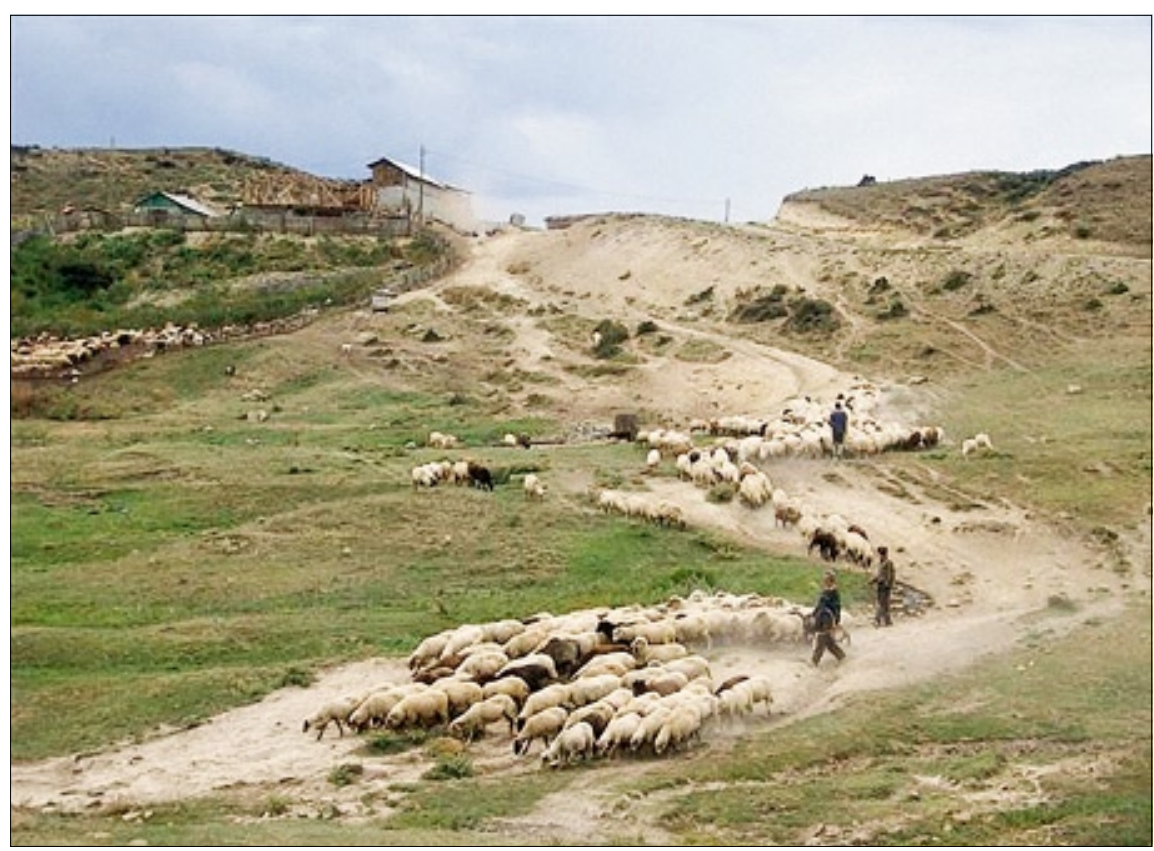

Plate 9 Sheep are traditionally kept at grazing stations ('stâne') on the high ground during the summer months although this example features the Subcarpathians of Buzău county cal authorities. The GEF blueprint project was initiated in 1997 for the 2000-6 period, building on the national biodiversity conservation strategy and action plan of 1996 (prepared with GEF/World Bank support). At national level, capacity builds on the MWFEP's National Forestry Agency that established Retezat National Park Administration as a sub-unit in 1999. GEF has helped establish proper boundaries and functional zones.

There is a dilemma over grazing because it is essential to maintain the present vegetation in the protection zone, but without heavy pressure. Yet this is not economically feasible and communities would like the park to buy the land, perhaps with EU subsidies helping in future. However in the buffer zone where higher stocking levels are possible, cooperation with local communities has been greatly assisted by a small grant programme funded by GEF and, to maintain goodwill, it is considered important that funding should be taken over after 2006 by others (perhaps the EU). There is a threat from the projected Uricani-Băile Herculane road that may isolate the Vâlcan Mountains from the Retezat/Godeanu massif and encourage a 'ring' of second home/tourism development around the park (as in the Tatra). Tourist pressure is broadly sustainable apart from damage through 'wild tourism' e.g. dumping rubbish and the cutting of Pinus mugho by fishermen for campfires. New chalets are proposed for Bucura in the core within the perimeter constellation of Gura Zlata, Gura Apei, Pietrele and Băleia - and link routes with Vâlcan (Oslea motel), Godeanu (Gugu) and Poiana Mărului (Sauă Iepei) - also motel Corcoaia at Cerna Sat (Niculescu 2004): part of a national programme to expand chalets and maintain/develop paths. More conventional rural tourism accommodation is available in 
the commune centres and the larger villages.

PIATRA CRAIULUI NATIONAL PARK (Ioraş et al. 2001; Muică et al. 1999) is one of 16 national and natural parks declared since 1989. Situated in Argeş and Braşov counties, it has exceptional scenic and biodiversity value although the flora and fauna are under threat from agricultural, forestry and tourism pressures. A $25 \mathrm{~km}$ limestone and conglomerate massif, with steep slopes and moving scree on either side connects the Bucegi and Făgăraş to the east and northwest respectively. There is a central role for forest management involving certification and the creation of forest user groups and community woodlands to reconcile conflicting interests in the forests and in wood processing. Forest user groups ('Asociații ale Proprietărilor de Pădure’: APP) are being formed by combining individual restitution parcels. Following the ten year forestry management plans, the forest resources could be managed sustainably and deliver to the APP members firewood, construction wood or cash (according to their preferences). The involvement of communities in forest management is now considered a realistic option to avoid fragmentation and retain the forest as a complex and valuable natural resource system while allowing decentralisation so that local interests to benefit in terms of income for poverty-alleviating wood consumption. Community involvement could be secured through constructive participation in generating wood products that could be marketed on the basis of quality and certification of sustainable management, although government may well need to offer financial incen- tives for community association and then on-going consultations will be needed between communities and the forest administration. Leases for extraction of non-timber forest products should be considered: some activities could be increased because although mushrooms, 'menta' (teaplants) and raspberries are collected by local people, only casual use is made of medicinal and other edible plants that might find niche markets. Small logging and sawmilling enterprises should be capable of harvesting unusual species and adding value through joinery, furniture production or the processing of mill offcuts.

Grazing Pressure has been increasing for sheep numbers exceed the optimum carrying capacity ten times: the population of some villages is double the level of the 1920s, while unemployment is increasing the level of dependence on small family farms. The high pastures are no longer as rich as they were: after about 60 days of grazing (out of a season that may last from 90-140 days, depending on the length of the previous winter) there are drastic changes in soil characteristics. The high meadows are exhausted and sheep are forced into the forests where the vegetation is richer in nutrients and water content. As they disperse they become less well protected by the dogs are fall an easy prey to large carnivores. The situation can only get worse if peasants continue to expand their flocks following a growth in the number of livestock using the massif pastures from 800 to 1,500 animals during 1989-1996 alone. Clearly, new and more efficient ways of livestock protection will be necessary: electric fences (which seem promising after limited experiments) or breeding improved guard dog. Meanwhile there may

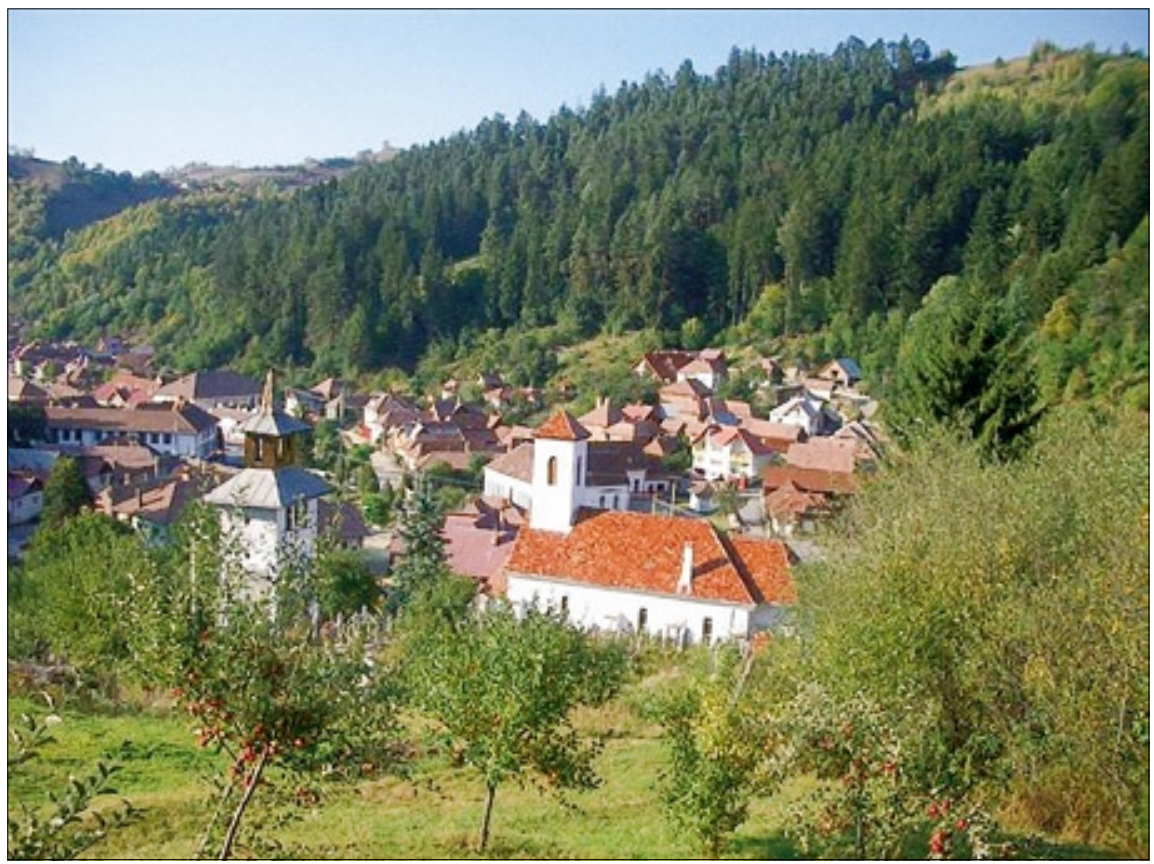

Plate 10 The village of Poiana Mărului in Braşov county: one of a cluster of villages catering for rural tourism in the Perşani and Piatra Craiului Mountains be reduced tolerance for carnivores and increased interest in the propagation of preferred game species like deer. However, if an infrastructure of pensions and services can be built up, and if money generated by the hunting business goes at least in part to the community and not just to the forest administration, large carnivores could benefit mountain communities through ecotourism is to the benefit of local people This will then increase support for their conservation. So ecotourism that addresses large carnivores among other things has a great potential in Romanian regional de velopment. It is attractive to rural dwellers as a means of upgrading accommodation and providing infrastructure the community can enjoy throughout the year. The Bran-Moeciu area has a flourishing rural tourism business, although it is related to mountain scenery in general, but relatively little has developed in the Zărneşti area closer to the Piatra Craiului.

Rural Tourism. Aftwer the first travel group arrived in 1995, a local pension opened in 1998 and two other families are now involved. So far costs exceed benefits but a growth in tourism could tip the scales and this would be particularly valuable in Zărneşti where there is high unemploy ment (Plate 10). The tourist agency started in 2000 and the local 'Asociație de Ecoturism Plăiuri Zărneştene' (AEPZ) started in the same year. There is now an attempt to set up a horse-riding centre in the Bârsa Valley linked with AEPZ so that the families providing accommodation will have a direct in terest, with other options being provided by rock climbing and survival training. A ' $\mathrm{Vi}$ sion for Zărneşti 2020' adopted by the town council in 1999 envisaged sustainable tourism based on local family businesses, sustainable industry and agro-forestry; also the maintenance of specific local architectural characteristics and protection for zones of high ecological value adjacent to the national park, like the Bârsa Valley when a planning application for a granodiorite quarry was rejected. A key issue however is a large carnivore centre (LCC) - on the Bavarian Forest National Park model - where visitors can get information and enjoy a wildlife enclosure. The LCC would have an exhibition and lecture hall; rooms for each animal and another set up as a shepherd camp; also enclosures for captive-bred carnivores and their prey species (including deer and wild boar), and a nature trail along with souvenir shops and catering facilities. Even so, more 'capacity' is needed to make conservation an important local issue and secure appropriate landuse planning in the sensitive Bârsa valley above Zărnești where the meadow vegetation is particularly important. It is also relevant to add that the resort of BranMoeciu lies on the margin of this area and is endowed with the major historic build- 
ing of Bran Castle given to Queen Marie in 1920 , seized by the communists in 1948 and restituted to Dominic de Habsburg in 2006. The castle has been maintained as a highly popular museum in recent years is highly relevant for Dracula tourism because although the locale for Bram Stoker's novel lies well to the north in BistrițaNăsăud county, the castle has associations with Medieval Wallachian prince Vlad Tepeş who was clearly a source of inspiration. It is hoped that the castle will remain available permanently as a tourist asset although the new owner's offer of sale to Braşov County Council for $€ 60 \mathrm{mln}$ has not been taken up.

THE DANUBE DELTA comprises a range of ecosystems within a complex of backwaters and sandbanks (nourished by river alluvia) through which flow the three arms of the Danube: Chilia, Sulina and Sf. Gheorghe. It has great importance for birds through the breeding, feeding and resting places available at the intersection of the main European migration routes (Figure 3). Over 300 bird species are to be found (with some 175 permanently present): arctic geese, cormorants, pelicans (including the endangered Dalmatian Pelican), white herons and birds of prey including the threatened Imperial Eagle. The delta has been exploited for fishing and navigation (in addition to subsistence farming by a scattered and ethnically-diverse population that includes a Lipovan minority descended froşşm eighteenth century Russian and Ukrainian refugees) but most threatening have been the large-scale exploitations for agriculture, reed harvesting and timber dating back to the late 1930 s and intensified under communism. Across the delta 97.4th.ha were dyked by 1990 with another 40.oth.ha in the course of preparation for agriculture, out of a total wetland complex of 180.0 in Romania and Ukraine (Marin \& Schneider 1997). Results were disappointing since the peaty ground was found to be unsuitable for agriculture (though the alluvial ground was good) and poor performance has to be seen in the context of high development costs and the loss of natural habitat. This was particularly unfortunate at Sireasa where development resulted in the loss of small lakes surrounded by reeds and hydrophytic plant associations and meadows interspersed with willow trees (very different from the landscapes associated with the large lacustrine complexes further east). The natural landscape was blotted out: there was an irreversible dryingout of peatland followed by luxuriant weed growth. There was also ecological damage through over-grazing and the discharge of fertiliser into the drainage system, encouraging the accumulation of algae and the

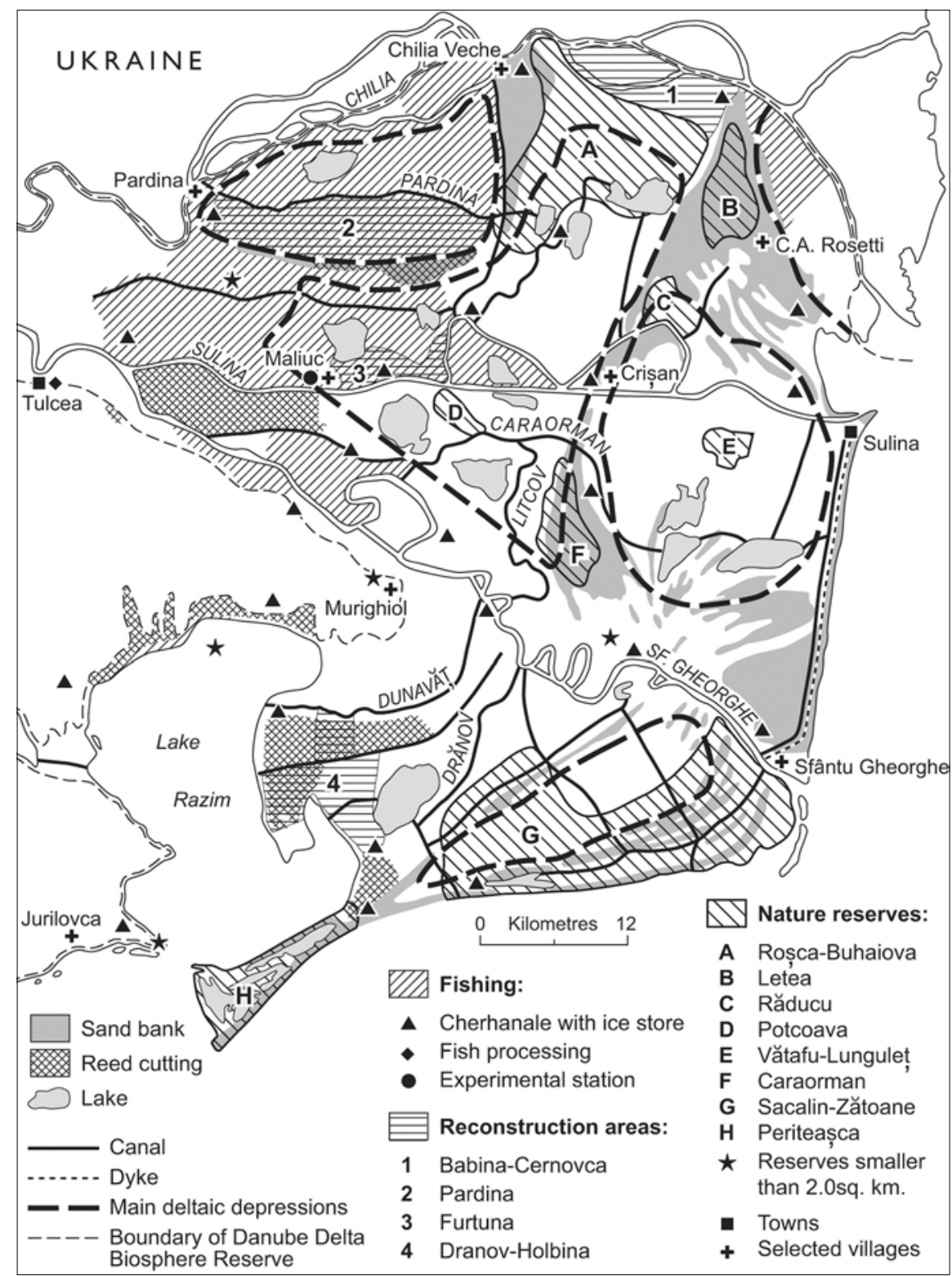

Figure 3 The Danube Delta

wider problem of eutrophication. The agri culture programme was complemented by plantations of Canadian poplar that displaced willow trees from the river banks and replaced from the natural oakwoods of Caraorman and Letea. This meant considerable losses of natural vegetation and faunal associations in the interest of economic efficiency.

Meanwhile, the water flow and sediment load declined (the latter barely 3omln.t/yr during the 1980 os but $67 \mathrm{mln} . t$ before 1960) - hence the accelerated erosion along the Black Sea coast. The Sulina-Sf.Gheorghe defensive barrier as well as the CrişanCaraorman Canal (to move mine production) in turn influenced water flow and the evolution of ecosystems (Driga \& Gâş̧tescu 1997; Gâştescu et al. 1999). And as the latter were threatened by the river's rising nutrient load from the 1970s, eutrophication through the growth of green algae reduced transparency and the reduction in dissolved oxygen in the deep water layer has destroyed the vegetation. The water system that favoured pike and tench was degraded while bream, roach, Prussian carp and zander became dominant: there was a very big rise in Prussian carp after 1972 and bream from 1980, while perch and tench were virtually eliminated by 1985 and pike by 1990 . There was also some industrial pollution from Tulcea while some fish spawning grounds were affected by sedimentation and eutrophication linked with sand mining at Caraorman. Reference may also be made to damage from waste water, inappropriate tourism and heavy metal pollution linked with the wars in former Yugoslavia (Gâştescu 1993). Hunting became more important as the deer population increased but burning (noted in 1993) to deny refuge for the deer damaged the floral habitats and their associated fauna. Formal protection began with Letea Forest in 1938 and the protected area reached 40.oth.ha by 1961 , including wetlands like Roșca-Buhaiova and Sacalin-Zătoane that 
sheltered pelican colonies (although there was no immunity from the exploitation going on roundabout since the Pardina farming project lay adjacent to the RoşcaBuhaiova reserve). The water surfaces in the delta shrank by $10 \%$ between the 1960 s and 1990 seflecting the scale of degradation. In 1991 the delta became a Ramsar site and UNESCO recognised the Danube Delta Biosphere Reserve (DDBR) after it was formally approved by the Romanian parliament. It covers 5,912sq.kms and includes 18 strictly protected areas of little-disturbed wetland and woodland ecosystems amounting to $526 \mathrm{sq} . \mathrm{kms}(8.7 \%$ of the total). There are also 13 buffer zones for the protection area totalling 2,233 sq. $\mathrm{kms}$ (38.5\%) and 3,061sq.kms (52.6\%) of economic zones comprising lakes and channels, bars and embankments, agricultureforestry-fishing areas and settlements. An administrative régime was stabilised in 1993 and the following year WB-GEF provided $\$ 4.5 \mathrm{mln}$ to enhance capacity for biodiversity management.

Ecological Recovery involved an international effort supported by the World Conservation Union, WWF and the French Cousteau Foundation. An international centre for education and training in environmental protection has been set up at Uzlina (on the Sf.Gheorghe Channel opposite Independența (Murighiol). This will provide a valuable basis for the tourist industry over the longer term. Three percent of the delta is set aside for ecological restoration: at Babina-Cernovca, Dunavăț-Holbina, Furtuna and Pardina (Gâştescu 1996) and water preservation strategies are another essential component of the DDBR management plan and a new outlet to the sea from the Caraorman Depression may be needed (Gâştescu 1995). But traditional activities are also supported in the interests of improved living standards for the local inhabitants. It was unfortunate that the administration's capacity could not be developed quickly enough during 1993-5 to accept funding and other assistance from EBRD and IUCN for a programme of ecologically sustainable development involving the private sector (Goriup 1994; 1995). However steps have been taken to improve the infrastructure of the villages and to develop the Tulcea-Sulina axis with a major refurbishment of Sulina including an airport and surfaced roads. There has been a pilot project in sustainable rural tourism, with a local association, founded in 1999, which can offer accommodation in typical houses. There is now a good range of accommodation, including small hotels and hotel boats, along with information and interpretation centres.

Wetland Rehabilitation has seen WWF playing a prominent role since a planning seminar was organised by the DDBR Au- thority at Uzlina and a baseline was agreed for restoration by various organisations (including IUCN and WWF) emphasising the importance of the hydrological regime and need for all restoration projects to be closely interrelated (Pascariu 1997). By 1993, after inspections involving the Danube Delta Research \& Design Institute, Auen-Institut Rastatt and the Directorate General for Public Works \& Water Management in Flevoland (The Netherlands), a restoration programme was agreed for Babina-Cernovca, Dunavăț-Holbina and Furtuna, while the southern part of Pardina was also proposed unofficially. With the backing of Workd Bank-GEF as well as the Romanian government and WWF International, WWF Germany took responsibility for Babina-Cernovca involving two small islands in the Chilia channel which had been transformed by the dyking that started in 1985 at Babina $(2,200 h a)$ and 1987 at Cernovca $(1,58 \mathrm{oha})$ with the aim of replacing the fishing-reed cutting economy (with some forestry and wildfowl hunting) by agriculture (Bandacu et al. 1993). Cernovca was earmarked for rice growing - with the groundwater level lowered by a network of drainage ditches (main and secondary canals) and pumping stations - but conversion work was never completed and only the western part was ever ploughed. The island consisted mainly of agriculturally unusable marshland, while high evaporation led to salinisation - through lack of inundation - meaning that the soil was only suitable for grazing. WWF found that the islands comprised embankments around depressions with lakes ('ghioluri'), small watercourses dry in summer ('japsche') and areas of gleyed soils that were temporarily flooded during March-April.

With the encouragement from the Chilia Veche commune, seeking improved fishing and grazing, the polders were opened at Babina in 1994 and Cernovca in 1996 (Paun et al. 1994). There was a rapid change from terrestrial to aquatic vegetation and more than half of the islands are now covered with reeds. Fish species increased from two in 1993 to 15 in 1995 with recovery of the natural species, while the avifauna changed dramatically as flooded pastureland was visited by ducks, herons, pelicans and terns. After a few years of uncontrolled natural development the islands natural resources will be returned to the local administration for traditional use: sustainable cattle grazing, fishing, hunting, reed cutting and ecotourism based on a management plan. Reconstruction so far has generated profits on the investment through increased fishing and tourism. It is worth adding that wetland conservation has been taking place at various sites along the Danube since 1990 with a coordinated programme facilitated by a Phare project published in 2000 and a Lower Danube Green Corridor (LDGC) concept agreed by Bulgaria, Moldova, Romania and Ukraine in the same year: the ultimate aim is to extend the LDGC to floodplains in all 12 Danubian countries to show how they can serve their natural functions - linked with a 'living river' - in terms of biodiversity conservation and provision of resources (water, fish and wood). The aim is to supplement 400,oooha of existing protected areas with 100,00oha of newly protected areas with some 250,0ooha of priority sites for restoration (some of which are included in the previous two categories) to create a continuous corridor.

Sustainable Development is being pursued by developing traditional activities in the context of trans-frontier cooperation with Moldova and Ukraine. Farmers must not use fertilisers in hunting and fishing areas in the interest of conserving biodiversity. Hunting is licensed only on agricultural land and efforts are being made to control poaching in the Danube meadows. It is important to ease pressure on the fish stock, since the fish catch fell from $16,000 t$ in 1986, to 12,000 in 1991 and 2,400 in 2002 before levelling off. To help recovery, Tulcea Chamber of Commerce started promoting fishing industry technology (including ocean fishing) by in the late $1990 \mathrm{~s}$ and altogether there were 1,723 licensed fishermen and 123 commercial companies fishing in the delta in 2002, with fishing areas leased according to fish quality, the operator' investment power and local job creation. Incomes have been boosted by subsidies to fishermen: in 2005 40,0oolei/ $\mathrm{kg}$ for sturgeon; 12,00o for perch/sheat and 10,000 pike for over $100 \mathrm{~kg} / \mathrm{species}$ at one delivery. The National Fish Stock Corporation is releasing sturgeon fries from Brateş hatchery (Galați) to repopulate the Danube; and a pilot project to restock Lake Razim with pike and perch has been implemented by the Lebada private fishing association whose fishery station (with fish processing, refrigeration and water purification) has been supported by the World Bank. Black Sea fish populations of horse mackerel, grey mullet and blue fish are growing again (though sturgeon, shark and plaice sunk to critical minimal levels in 2001). But shoals of plaice (recently thought extinct) have been found in the delta. Ukraine's decision to cut the 8.okm Bystroye Canal in 2004 damaged spawn ing grounds (as well as bird nesting areas) not to mention the noise disturbance and the dumping of contaminated mud. Moreover a deeper Chilia channel could draw water from under Letea Forest.

Rural Tourism: Infrastructure. The remoteness of the settlements means that new infrastructure must address the needs of the local population as well as tourists. 
The Tulcea-Chilia road is now compete as a stone road, except for $15 \mathrm{kms}$, and is passable except in very wet weather (Dobraca \& Dobre 2000). But there is a also case for a connection from Sulina to Cardon and the Letea sandbank; also from Tulcea to the Sulina canal settlements. A cell telephone network financed through Phare is serving up to 1,80o subscribers in Crişan, Mahmudia, Maliuc, Mila 23 and Murighiol, while drinking water supplies and sewerage are another priority. The expansion of tourism raises concerns but the income could help reduce dependence on fishing. Local involvement is crucial in order to protect traditional culture. Mass tourism is obviously ruled out by the priority for conservation, not to mention the mosquito problem, but experts now think the delta can accommodate over 130,00o tourists annually - far more than the 36 ,000 who actually arrived in 2001: 20,000 on their own and the rest in organised groups. However this was an increase over the 4,400 Romanians and 9,00o foreigners who arrived in 1996, when the reserve authorities imposed very severe limits to avoid ecological pressure and approved high tariffs as a discouragement! Since them the tourism ministry has proceeded with an aggressive campaign to promote the delta's biodiversity with information and ecological education in 2001 through centres at Crişan and Sulina as well as Tulcea with World Bank and EBRD co-finance and help from Germany's Rastatt Institute.

As a large administrative centre approaching 100,000 inhabitants, with hotels and the important Danube Delta Museum, Tulcea is well-established as the tourist capital of the delta; enjoying road, rail and water access as well as domestic services from the airport at Cataloi. Elsewhere tourism is based at hotels/motels at Crișan, Maliuc, Roşu Lake and Sulina - supplemented in 2002 by the new Teo Hotel on the Sf.Gheorghe branch near Mahmudia (a 2obln.lei investment); also camping at $\mathrm{Ba}$ badag, Crişan and Murighiol. The reserve administration supports a rural tourism concept of small villas in hotel compounds with small boats for sightseeing; also the rehabilitation of infrastructure for Sulina, announced in 2003 after the Danube Delta Friends Foundation proposed the regeneration of the town to make best use of the cultural patrimony (after the town had previously been linked with the abortive Europa resort project). A popular strategy is to drive to Murighiol and take boats down the Sf.Gheorghe arm to the Uzlina lake network. Meanwhile routes from Crişan lead to (a) Matița and Furtuna lakes and (b) Caraorman and the Sf.Gheorghe channel; also from Jurilovca to the Razim Lake and Gura Portiței. Against a background of unregulated development of nomenclat-

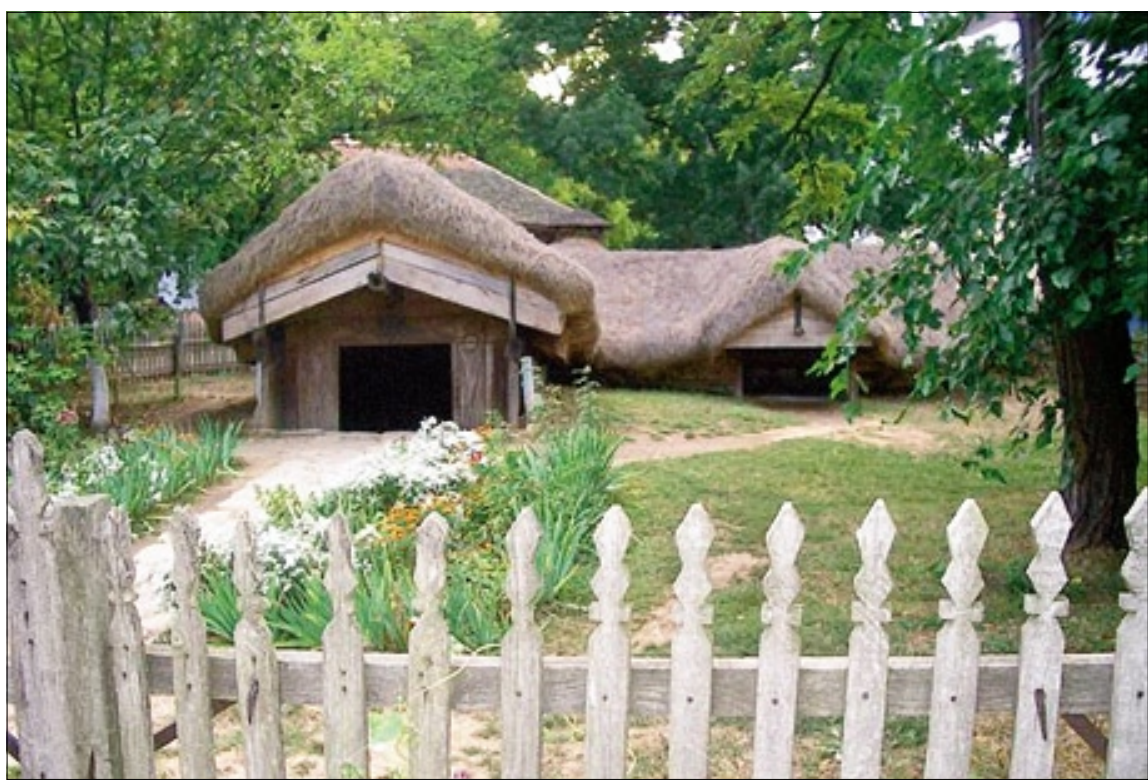

Plate 11 A traditional fisherman's house from the Danube Delta photographed in Bucharest's 'Village Museum'

ura holiday homes in the past, the development of a network of family agrotouristical pensions was launched at the end of the 1990 os to install a property-owning population in a rural area where over $60 \%$ do not own their land. Austria has given $\$ 25,000$ for the C.A.Rosetti ecotourist pilot zone that covers C.A.Rosetti and four other villages on the Letea sandbank (Cardon, Letea, Periprava and Sfiştofca). Oth er funding came from the World Bank and Tulcea CC.

Rural Tourism: New Projects. Tourist statistics which show a growth in capacity from 565,000 bed-nights in 1994 to 664,000 in 1995 , but then a slide to 333,000 in 2003 , while utilisation fell from 26.6 to $21.9 \%$ during 1994-5 and hovered around the latter figure ever since. There were nevertheless almost 37,000 visitors in 2003 and $22.6 \%$ of them were foreigners. However the rural component has grown from just four establishments in 2000 to 27 in 2003 , offering a total of 310 beds. Accommodation is frequently provided in the houses of fishermen at Caraorman, Crișan (a small cluster of six houses), Mila 23, Murighiol, Niculițel, Periprava (a base for Letea Forest), Sf. Gheorghe and Sulina - where meals of 'borsch' (thick soup) and 'plachie' (cooked fish with onion and oil) are an at traction (Plate 11). There is also similar accommodation extending further up the Danube valley (Aliman, Dunăreni, Oltina, Ostrov and Topalu) with a focus on fishing and hunting parties. The local agrotouristical administration is up-beat about the prospects for a shift in emphasis from fishing to tourism and seeks World Bank and UNESCO assistance for $\$ 2.0 \mathrm{mln}$ worth of delta projects involving microcredits for fishing and medicinal herb growing as well as farm tourism. Eden Holiday Village - a delta tourist base accessible only by boat has been inaugurated at Gura Portiței (between Lake Razim and the Black Sea) with 300 places in log cabins or superior airconditioned buildings, following a $€ 1.1 \mathrm{mln}$ investment in 2002 by Marian Matache's Pescicola Tour Company that deals with fishing and reed processing. There is now a five-star British-American delta nature resort project for a new luxury ecological complex at Parcheş 2okms west of Tulcea, accepted by DDBR and Somova commune. Up to $\$ 5.0 \mathrm{mln}$ has been invested since 2003 in a village of bungalows on a 15 ha site with a wide range of facilities (restaurant, bar, disco, club, sports and riding) as well as a private beach, a nautical base (with motor boats and fishing gear) and watchtowers (now for ornithologists and photographers rather than military guards!

The plans were drawn up by a Londonbased architectural company in consultation with the reserve authority, based on the idea of Indian businessman Dirwaker Singh. Floating hotels are another feature, provided for example by the Romanian-French company 'Nouvelles Frontières Simpaturism' since 1997 and from 2003 by Gentila of Câmpia Turzii (a readymade clothing company operating a modern ship carrying 15-25 people on several routes, with financial assistance from grant from Ministry of Development \& Forecasting under the 'Access Danube Delta Programme'). However tourism creates some problems of disturbance through the proliferation of motor boats, not to mention the increase in Danube cruise ships from just six in 2003 to 150 in 2004 and 400 booked 2005. For example, since 2002 the ministry (through Karpaten Tourism) has been operating Danube tours in connection with Seetours (Germany) who own two 3,49ot five-star luxury cruiseships ('Rosa Bella' and 'Rosa Donna' - built 
in Rostock and supplied with furniture in Constanța) offering 10-day $€ 5,000$ cruises from Passau to Sulina. While it is understandable that the cruise business should be encouraged (in the aftermath of the closures sparked by the Kosovo War) by more attractive Romanian ports and the 'Cruises of the Danube' programme from 2002 - with programmes by TUI, Hapag Lloyd, Peter Deilman, Pheonix Reisen and Scylla Tours - there is a danger from excessive navigation and the powers of the biosphere reserve authority may not be strong enough.

\section{Conclusion}

Romania's tourist industry has struggled to reorganise since 1989 and with very limited foreign investment attracted during the 1990 os there were relatively few domestic enterprises with the capital resources to undertake any radical restructuring. Alterative tourisms offered a way forward on the basis of fiscal incentives to invest the modest sums required to provide relatively simple accommodation in rural areas; especially given the support of the Romanian NGO NARET and foreign assistance through OVR and EU Phare. A promising start has been made in several areas and it is clear that there is potential in areas that are able to develop an identity and benefit from the promotional efforts of foreign tourist agencies, especially those specialising in niche tourism. The work being done in the field of ecological reconstruction and management in the Danube Delta and such mountain areas as the Piatra Craiului and Retezat should maintain the momentum for growth although there is an important opportunity on the domestic front as family incomes increase because more Romanian should be encouraged to take holidays at home based on the country's ample cultural and ecological resources.

\section{References}

Bandacu, D., Moldovan, M., Nichersu, M., Paun, A. 1993. Reconstrucția ecologică de la ipoteze la realitate. Analele Ştiințifice al Institutului Delta Dunării 2, 267-75.

Benedek, J., Dezsi, Şt. 2006. Rural tourism in Romania: the characteristics of the tourist offer. R.Petrea ed., Rural tourism and sustainable development (Oradea: Editura Universităţii din Oradea), 55-70.

Bennett, G. 1998. Guidelines for establishing the Pan-European Ecological Network in Central \& Eastern Europe': P.Nowicki ed., The green backbone of Central \& Eastern Europe (Tilburg: European Centre for Nature Conservation), 183-187.
Boar, N. 1999. Turism transfrontalier maramureşean: circulație transfrontalieră. Analele Universității din Oradea: Geografie 9, 76-80.

Boar, N. 2001. Impactul rețelei de transport asupra relațiilor transfrontaliere din spațiul maramureşean. Comunicări de Geografie 5, 525-30.

Buza, M., Dimen, L., Pop, G., Turnock, D. 2001. Environmental protection in the Apuseni Mountains: the role of environmental non-governmental organisations. GeoJournal 55, 631-53.

Dezsi, Ş., Bădărău, A.S., Meier, A. 1999. The natural protected areas from Maramureş county: the impact of touristic activities and principles of developing sustainable tourism. Analele Universitătii din Oradea: Geografie 9, 95-104.

Dobraca, L., Dobre, S. 200o. Tendințe actuală în organizarea spațiului geografic în Delta Dunării. Comunicări de Geografie 4, 469-76

Driga, B., Gâştescu, P. 1997. Modificările sistemului circulației apei în depresiunea Roşu-Puiu-Lumina. Revista Geografică 4, 38-45

Gâştescu, P. 1993. The Danube delta: geographical characteristics and ecological recovery. GeoJournal 29, 57-67.

Gâştescu, P. 1995. Contributions to the coastal zone management of the Romanian sector of the Black Sea. Revue Roumaine de Géographie 39, 71-8.

Gâştescu, P. 1996. The Danube Delta Biosphere Reserve: present state and management. Revue Roumaine de Géographie 40, 27-33.

Gâştescu, P., Driga, B. Ciupitu, D., Chendeş, V. 1999. Modificări în sistemul circulației apei în depresiunea Sireasa-Furtuna. Revista Geografică 6, 136-44.

Ghinea, D. 1993. Romania: resorts and spas (Bucharest: Editura Enciclopedică).

Goriup, P. 1994. Biodiversity ecological investment and sustainable development in the Danube Delta Biosphere Reserve, Romania. Ecos 14, 45-51.

Goriup, P. (eds.) 1995. Management objectives for biodiversity conservation and sustainable development in the Danube Delta Biosphere Reserve, Romanua (Newbury: Nature Conservation Bureau).

Ielenicz, M., Dumbrăveanu-Andone, D. 1997. The tourist potential of the Carpathians. Light, D., Dumbrăveanu D., (eds.), Anglo-Romanian geographies: proceedings of the second LiverpoolBucharest Geography Colloquium (Liverpool: Liverpool Hope Press), 59-64.

Ilieş, M., Ilieş, G. 2006. Rural tourism of Romania presented on www.google.ro' : R.Petrea ed., Rural tourism and sus- tainable development (Oradea: Editura Universității din Oradea), 45-54.

Ioraş, F., Muică, N., Turnock, D. 2001. Approaches to sustainable forestry in the Piatra Craiului national park. GeoJournal 55, 579-98.

Marin, G., Schneider, E. (eds.) 1997. Ecological restoration in the Danube Delta Biosphere Reserve, Romania (Tulcea: DDBRA/WWF).

Moldovan, F., Moldovan, V. 1995. Le rôle de l'opération villages roumains dans la réconstruction rurale. Anale le Universităţii de Vest din Timişoara: Geographie 5, 62-71.

Muică, N., Roberts, L.A., Turnock, D. 1999. Transformation of a border region: dispersed agricultural communities in Braşov county, Romania. GeoJournal 46, 305-17.

Niculescu, D. 2004. Revigorarea turismul montan. Revista Geografică 10, 205-9.

Nowicki. P. 1998. The Cracow Declaration. in: Nowicki, P. (ed.) 1998. The green backbone of Central \& Eastern Europe (Tilburg: European Centre for Nature Conservation), 257-262.

Paun, A., Curelariu, G., Grigioraş, C. 1994. Caracterizarea ecopedalogică a ostrovului Babina în vedere fundamentarii masurilor de ameliorare a starii ecologice actuale. Analele Ştiințifice al Institutului Delta Dunării 3, 275-80.

Petrea, R. 2004. Turism rural în Munții Apuseni (Oradea: Editura Universității din Oradea).

Petrea, R., Petrea, D. 200o. Turism rural (Cluj-Napoca: Presa Universitară Clujeană).

Ploaie, G., Turnock, D. 2001. Public perception of environment in the mountains of Vâlcea County. GeoJournal 55, 683-701.

Surd, V., Turnock, D. 2001. Romania’s Apuseni Mountains: a safeguarding a cultural heritage. GeoJournal 50, 285-304.

Turnock, D. 1999. Path dependency and sustainable rural tourism in the Romanian Carpathians (Leicester: University of Leicester Department of Geography Occasional Paper 41).

Turnock, D. 2002a. Prospects for sustainable rural cultural tourism in Maramureş, Romania. Tourism Geographies 4, 62-94.

Turnock, D. 2002b. The Carpathian ecoregion - a new initiative for conservation and rural tourism: the case of Maramureş'. Journal of Tourism 5 21-39.

Ureche, C., Ureche, I. 1997. Le tourisme comme moyen de développement de l'espace pluridisciplinaire (Cluj-Napoca: Editura Risoprint) ,154-158.

Wortthelet, D. ed, 1997, Au pays des villages roumains (Bruxelles: Opérations Villages Roumains). 